\title{
Low Cost Performance Evaluation of Passive Solar Buildings
}

Larry S. Palmiter

L. Blair Hamilton

Michael J. Holtz
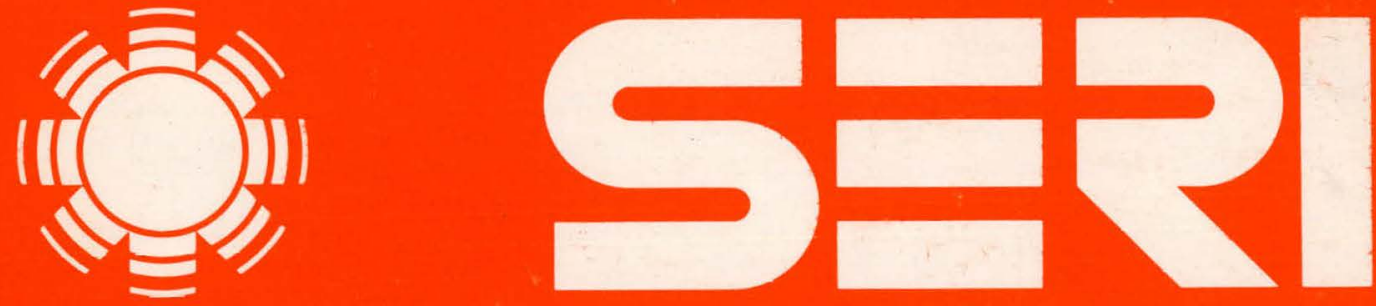

Solar Energy Research Institute

A Division of Midwest Research Institute

1536 Cole Boulevard

Golden Colorado 80401

Operated for the

U.S. Department of Energy

under Contract No. EG-77-C-01-4042 


\section{DISCLAIMER}

This report was prepared as an account of work sponsored by an agency of the United States Government. Neither the United States Government nor any agency Thereof, nor any of their employees, makes any warranty, express or implied, or assumes any legal liability or responsibility for the accuracy, completeness, or usefulness of any information, apparatus, product, or process disclosed, or represents that its use would not infringe privately owned rights. Reference herein to any specific commercial product, process, or service by trade name, trademark, manufacturer, or otherwise does not necessarily constitute or imply its endorsement, recommendation, or favoring by the United States Government or any agency thereof. The views and opinions of authors expressed herein do not necessarily state or reflect those of the United States Government or any agency thereof. 


\section{DISCLAIMER}

Portions of this document may be illegible in electronic image products. Images are produced from the best available original document. 
Printed in the United States of America Available from:

National Technical Information Service

U.S. Department of Commerce

5285 Port Royal Road

Springfield, VA 22161

Price:

Microfiche $\$ 3.00$

Frinted Copy $\$ 5.25$

\section{NOTICE}

This report was preparcd as an account of work sponsored by the United States Government. Neither the United States nor the United States Department of Energy, nor any of their employees, nor any of their contractors, subcontractors, or their employees, makes any warranty, express or implied, or assumes any legal liabiiity or responsibility for the accuracy, completeness or usefulness of any information, apparatus, product or process disclosed, or represents that its use would not infringe privately owned rights. 
SER I /RR -63-223

UC CATEGORY: UC-59B

LOW COST PERFORMANCE EVALUATION

OF PASSIVE SOLAR BUILDINGS

LARRY S. PALMITER

L. BLAIR HAMILTON

MICHAEL J. HOLTZ

OCTOBER 1979

This book was prepared as an account of work sponsored by an agency of the United States Government. Neither the United States Government mor any agency thereol, nor any of their employees. makes any warranty. express or implied, or assumes any legal liability or responsibility for the accuracy, completeness. of usetulness of any intormation, apparbius, product, of process disclosed. of represents that ins use would not iniringe privately owmed rights. Reference herein to any specitic commercial product. process, or sevvice by trade rome. tracemerk. manufacturer, or otherwise, dous Ste con necessar ily state or reflect those of the Unired States Government or any ageney thereat.

PREPARED UNDER TASK No. 6322.30

PASSIVE TECHNOLDGY PROGRAM

\section{Solar Energy Research Institute}

1536 Colc Boulevard

Golden, Colorado 80401

A Division of Midwest Research Institute

Prepared for the U.S. Department of Energy

Contract No. EG. $77 \cdot \mathrm{C} \cdot 01 \cdot 4042$ 
THIS PAGE

\section{WAS INTENTIONALLY LEFT BLANK}


FOREWORD

The thermal performance evaluation of passive solar buildings is an evolving area of research. Not only are the performance factors difficult to define but the methods of instrumentation and analysis are as varied as the passive designs being monitored. The work performed here under Task 6322.30 has provided an opportunity to address these difficult issues and to propose a possible solution. This work should be seen as one part of the Passive Performance Data Acquisition and Analysis Program of the National Passive/ Hybrid Solar Heating and Cooling Program.

The Passive Technology Branch is greatly indebted to Larry Palmiter and Blair Hamilton of the National Center for Appropriate Technology who organized the meetings and wrote this report. We would also like to thank Douglas Balcomb of Los Alamos Scientific Laboratory, William Ducas of the National Bureau of Standards, and Ronald Kammerud of Lawrence Berkeley Laboratory for their constructive comments and criticism throughout the project and Norman Saunders, Evan Brown, David Marke, Charles Fowlkes, Harold Taylor, and Ron Campbell, who openly discussed their own efforts to develop low-cost data loggers.

We hope this report is informative and immediately useful for the evaluation of the performance of passive solar buildings. The Passive Technology Branch has awarded five contracts to develop prototype low-cost data acquisition systems that meet the equipment specifications described in this report. These systems, to be received at SERI in the fall, will be carefully evaluated and one or more systems selected for a larger purchase and installation in passive solar buildings throughout the country. In this manner, we will begin the process of assembling the technical basis for verifying the performance of passive solar buildings in numerous climates. We are hopeful this information will assist in the faster and wider application of passive systems in U.S. buildings.

Approved for:

SOLAR ENERGY RESEARCH INSTITUTE
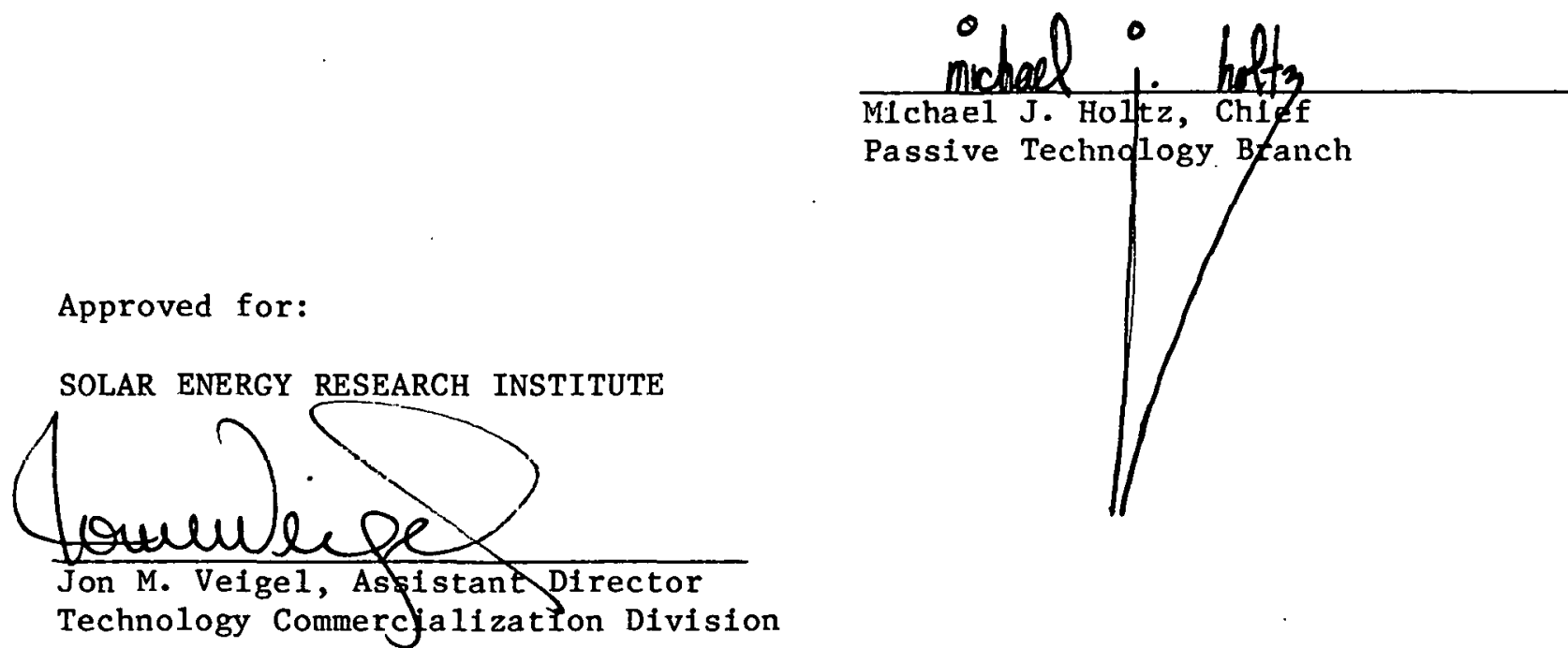
THIS PAGE

\section{WAS INTENTIONALLY \\ LEFT BLANK}


TABLE OF CONTENTS

$\underline{\text { Page }}$

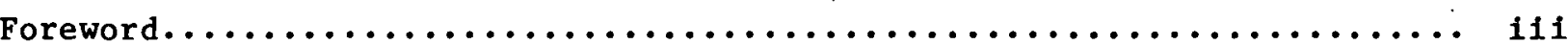

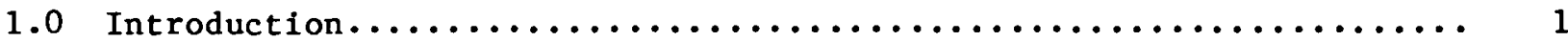

2.0 Therma1 Performance Factors........................... 3

2.1 The NBS Proposal for Thermal Performance Factors........... 4

2.2 Other Proposals for Thermal Performance Evaluation........... 7

2.3 Working Meetings on Low-Level Monitoring and Evaluation....... 8

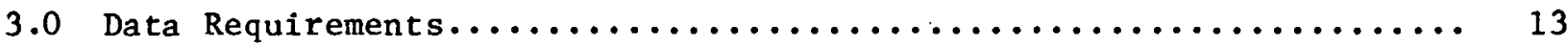

4.0 Measured Quantities................................ 19

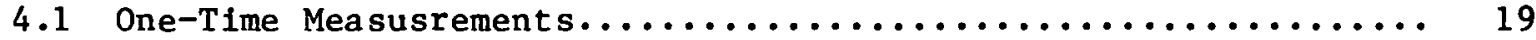

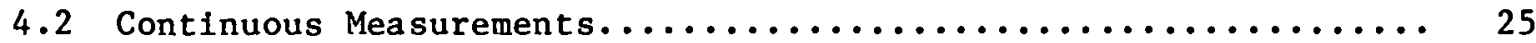

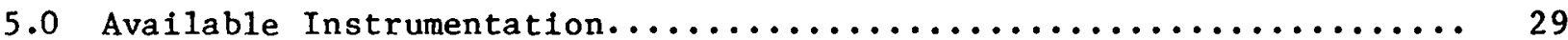

5.1 Available Instrumentation--Sensors................... 29

5.1 .1 Temperature Sensors......................... 29

5.1 .2 Temperature Sensor Shielding.................. 30

5.1 .3 Solar Radiation Sensors...................... 32

5.1 .4 Electric Power Use Sensors..................... 34

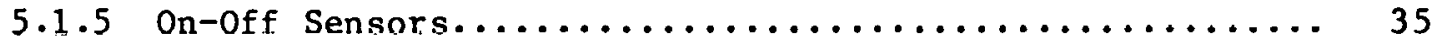

5.2 Available Instrumentation--Data Acquisition Systems......... 35

6.0 Recommended Instrumentation and Processing................. 39

$7.0^{\text {References } \quad \ldots \ldots \ldots \ldots \ldots \ldots \ldots \ldots \ldots \ldots \ldots \ldots \ldots \ldots \ldots \ldots \ldots \ldots \ldots \ldots \ldots \ldots \ldots}$

Appendix A A Comparison of Performance Factors

For Passive Solar Heating...................... A1 


\section{THIS PAGE}

\section{WAS INTENTIONALLY \\ LEFT BLANK}


LIST OF TABLES

Page

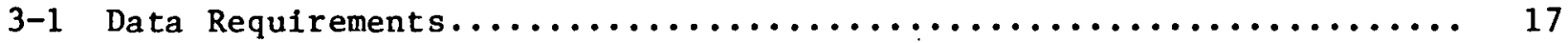

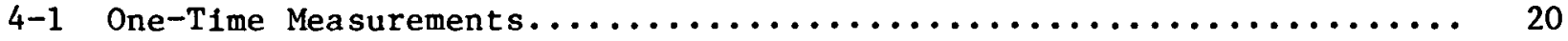

4-2 Continuous Mea surements............................ 20

5-1 Comparison of Typical Avallable Temperature

Sensors for Low-Cost Instrumentation.................... 31

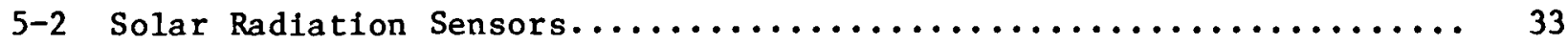

6-1 On-S1te Performance Summary........................... 42

LIST OF FIGURES

Page

5-1 Radiation Shield............................... 32 


\section{INTRODUCTION}

of the many renewable energy technologies under development in the United States, passive solar heating is among those most ready for commercialization [1]. While continuing research and development efforts is useful, technical feasibility has been demonstrated and cost effectiveness appears very attractive for numerous designs in a wide variety of locations [1].

Among the key barriers to commerclalization Identified by the U.S. Department of Energy (DOE) is the lack of quantitative performance information on various passive solar designs. If passive solar heating is to be integrated into the normal design process, design professionals need to know the quantitative differences in projected performance of varlous passive solar and conventional options for their particular location. To accomplish this with the use of design tools such as thermal models, their predictive capabilities need to be validated with measured performance data. Lenders will want evidence that a proposed building design will achieve the projected savings associated with it to be convinced of the cost effectiveness of solar design. Consumers need more than claims and calculations they may not understand before they will Invest more in a building for its passive solar features. Policy makers also need more quantitative information on passive solar system performance so that its impacts and benefits can be compared to those of other technologies. Incentive programs, for instance, should be based on accurate projections of the energy and economic impact of wide-spread use of passive solar design and such projections must be based on actual performance.

The further development of passive solar technologies through research also requires far more measured performance data than has yet been available. Whenever high quality, quantitative data on the thermal performance of passive solar buildings has been available, significant research which has advanced the state of the art has been a direct result. Unfortunately, such data has been made avallable only for certain types of systems and buildings in a few locations. While researchers can pursue theoretical techniques for system selection and optimal component sizing, such techniques must eventually be based on or validated with measured performance data.

Despite these and other expressed needs for measured performance evaluation, only a few bulldings and test rooms have been monitored adequately to yield the quality of data called for above. A 1978 survey of monitored passive solar building conducted by the AIA Research Corporation [2] listed 44 residences, 6 commercial bulldings, and 16 test cells. Less than half of these were reported to have adequate data for determination of basic performance factors and most were performed in a few climatic regions. The variety of methods used for measurement and analysis made comparison almost impossible except where side-by-side measurements were made by the same researchers 
(e.g., the test cells and Ghost Ranch buildings evaluated by Los Alamos Sc1entific Laboratory).

Minor changes in microclimatic conditions, occupancy, and architectural detalling can cause significant variation in the thermal performance of passive solar bulldings. This sensitivity makes it very difficult to generalize about the performance of passive solar bulldings without examining variations in performance under numerous different conditions.

Al1 these considerations suggest that a large number of passive solar buildings need to be monitored. Obviously, cost is a problem in considering many sites. The high cost of previous solar performance data programs such as that presently assoctated with the HUD and DUE Solar Demonstration Program has suggested the need for an alternative, low-cost approach for use with passlve solar bulldings. An alternative approach could also offer simplicity and increased usefulness (through local avallability and analysis of data) over the approach used in the Demonstration Program.

This report explores the possibilities of such low-cost, low-level monitoring approaches to thermal performance evaluation of passive solar buildings. Various methodologies are discussed and evaluated. Avallable instrumentation is surveyed. Definitions for various thermal performance factors are suggested. Recommendations are made for data requirements, instrumentation, and data processing for a method which would make possible the performance evaluation of a large number of passive solar buildings at a minimum cost.

The method proposed in this report is not applicable for all buildings. It works best with small residential and commercial buildings in cold climates. Only space heating is addressed. Passive cooling and cooling loads in general are not considered, and the method must be expanded and modified to include cooling, perhaps based on the current work of other researchers $[3,4]$. Butldings that use solid fuels as an auxiliary energy source are not considered (but might be within the framework of the proposed methods). Despite these and other limitations, the authors still feel that the approach suggested 1u this report offers an attractive, easily implemented alternative to high-cost monitoring and evaluation.

This report has been written in an effort to define the equipment necessary for low-level performance evaluation of passive solar buildings. Numerous assumptions were necessary regarding the needs for data, the definitions and use of performance factors, and the organization of a performance evaluation program. These issues are not the intended focus of this report; however, it is necessary to discuss them at length and make assumptions regarding them because there is no national plan for performance evaluation of passive solar buildings at this time.* It is hoped that this report, together with the current efforts of others on related topics, will assist in developing such a comprehensive plan.

* At the time of this printing a draft passive performance evaluation plan has been prepared and is undergoing review and modification. 
SECTION 2.0

THERMAL PERFORMANCE FACTORS

Almost every evaluation of thermal performance for solar heating and cooling has made use of some index of system performance. Often this is "percent solar heated" or "efficiency." Other factors range from "normalized auxiliary energy" to "equivalent energy saved" and a complete list would probably contain over 100 such terms. There is no question that such terms are useful for comparative purposes. They are the bottom line of most cvaluations.

The variety of terms is largely due to the different interests and data requirements of various concerned groups and individuals. The solar designer or architect will be concerned with information on the relative performance of various design options and combinations to guide future design decisions. An engineer may want detailed information on the dynamic performance of components to improve thermodynamic models or optimize sizing. Buflders will want information which can improve the marketability of a building. Occupants may want to know only how much energy they have saved. Policy makers may want to compare the overall impact of passive solar buildings on national energy usage.

Most data users want very different performance factors. In some cases, a comparison to "typical" conventional houses is desired. In others, it is a comparison to the same house "without solar." In some cases, it is important to isolate the effects of the "solar heating" from the rest of the building design (a difficult problem in passive systems because it is difficult to identify where sound building design stops and passive solar heating begins) and in others, only the combined performance matters.

Due to both the varying data requirements of the many users and the lack of recognized common definitions of performance factors for passive solar buildings, numerous definitional conflicts have become common. This has serlous implications, particularly in making comparisons of passive solar buildings evaluated by different researchers.

When questioned as to what, specifically, they would like to know about the thermal performance of a solar bullding, data users frequently respond in terms of "energy saved," "fuel savings," or "useful solar energy delivered." The quotation marks emphasize the lack of standard definitions. Although a 11 of these terms imply a comparison of the heating energy requirements of the passive solar design with an alternative design, the procedure used to define the alternative design and the rules used for making the comparison vary from one researcher to another. Several examples in the following sections of this report illustrate the significance of this problem, show how it occurs, and present some proposals for dealing with 1 t. 


\subsection{THE NBS PROPOSAL FOR THERMAL PERFORMANCE FACTORS}

In an effort to standardize evaluation procedures for solar heating systems, Ducas et a1. [5] of the National Bureau of Standards (NBS) have proposed a systematic classification of passive solar buildings, thermal data requirements for evaluation, definitions of performance factors, and recommended evaluation procedures. Two measurement levels are described in detail. The first uses extensive instrumentation to provide detailed measurements that reportedly allow for complete evaluation of component and system performance. In the second level, only building auxlliary energy and inside and outside temperature are measured. This NBS proposal is presently being revised and the observations and references regarding it in this report should be re-examined when the new version is made avallable.

While the detalled-level instrumentation and evaluation proposed by NBS is too expensive to meet the requirements of this program for low-level, low-cost thermal evaluation, the second-level instrumentation proposed would not provide the thermal performance information desired by many of the data users mentioned above. To determine an intermediate level of instrumentation while maintaining consistency with the standard evaluation framework NBS is trying to establish, it may be useful to review the relevant performance of factors proposed by NBS and their interrelationships. Each of these performance factors has been given an identifying designation by NBS similar to those used for active solar systems [6]. These designations will appear in parenthesis after each description of a performance factor in the following discussion.

When using the detailed level of measurement proposed by NBS, the most relevant performance factor in arriving at an index of "energy saved" is "solar energy ut1lized" (Q400). This factor is determined by a direct measurement of the net heat flow from the solar elements to the heated space. The way in which it is calculated depends on the type of passive system under consideration. For a storage wall heating system, it is found by adding the net heat flux from the rear of the storage wall to the space, to the net heat delivered through the thermocirculation ducts. For an isolated system, it is the measured heat delivered to the space either directly or from a storage element. For a direct-gain system, it is taken as the solar energy transmitted through the glass minus losses through the glass. Particularly in complex or hybrid systems, this direct measurement approach can result in extensive instrumentation requirements and numerous potential sources of error.

The second critical variable to be measured in the detailed level is the input energy to the heating system. Multiplying the calculated efficiency of the auxiliary system times this auxiliary input energy gives the amount of heat delivered to the space from the "auxiliary for space heating" (Q401). The sum of heat delivered from solar ("solar energy utilized") (Q400) and heat delivered from auxlliary ( $Q 401$ ) is taken to be the "space heating load" (Q402). The assumption here is that $100 \%$ of the heat delivered by the solar system is "utilized." However, in most cases, this will be true only when all 
excess heat input is stored. During periods of mild temperatures and high solar availability (a significant condition at most sites and one which can occur almost all year in some locations), load determined as total heat input will also include heat removed by ventilation or otherwise lost and not usefully contributed toward meeting the actual load.

Several "energy saved" factors are derived at this point depending upon whether the auxiliary heat is electric or fossil. For an electric auxiliary, the electric input energy for the heating element (Q409), the "auxiliary operating energy" (Q403) (1f any), and the electric input energy for operating the solar system ( $Q 102$ ) (if any), are added together to calculate the "total electric energy for space heating" (Q413). Electric input energy for conventional space heating $(Q 414)$ is then defined as the space heating load (Q402) divided by the efficiency of the electric auxiliary system. The "equivalent electric energy saved" ( $Q 415)$, defined as the difference of these numbers, represents the energy saved comparing the measured electric consumption of the passive structure with the calculated consumption of an all-electric heated structure with the same space heating load (Q402). Thus, any bias in determining space heating load is reflected in the "energy saved" (Q415).

For a fossil auxillary, the fossil fuel required by a conventional system (Q402) is divided by the auxiliary system efficiency. This is called "fossil energy for conventional space heating" (Q416). Subtracting the actual input "fossil energy for auxiliary" (Q410) ylelds the "equivalent fossil energy saved" (Q417). This energy saved factor also depends upon the accuracy of the space heating load calculation.

Both of these energy saved factors are based on a comparison between the energy requirements of the passive building and the calculated energy required for the same building if there were no sunshine and the heating system were operated to maintain the same interior temperatures. Heat gains from lights and appliances are assumed to be identical in both cases. Potential savings in electrical energy used due to electric lighting requirements being displaced by natural lighting are not considered. As noted above, any overheating which results in heat removal through ventilation or air conditioning will, in the above method, be reflected in unrealistically high "space heating load" and "equivalent energy saved" values.

A method is also provided in the NBS proposal for the comparison of two different bulldings, elther solar or non-solar. Since the amount of heating energy required is sensitive to the indoor and outdoor temperatures, when comparing different buildings it is necessary to make an adjustment for any temperature differences. Also, heating energy is dependent upon the size of the structure. This is dealt with by introduction of a space heating normalization factor (N444) defined as

$(\Delta \mathrm{T}$ reference)

( $\Delta T$ actual) (floor area) $^{\circ}$ 
This divides an energy quantity by the actual temperature differences between inside and outside giving energy per unit floor area and temperature difference. This is divided by the floor area to give energy per unit floor area and temperature difference, then multiplied by a reference temperature difference (undefined). Now, factors like normalized auxlliary energy (Q444) (N444 multiplied by either the electric or the fossil auxiliary input energy) can be determined. From this, normalized auxiliary energy for two building scan be compared. Subtraction produces the "energy saved comparison" (Q446).

Since the reference temperature difference is undefined in the NBS paper, it is not possible to evaluate this "energy saved comparison." The intention is olearly to provide a means to adjust for huildings of different sizes, in different climates, and with different indoor temperatures. Since buildings respond differently to radiation, lighting, appliance usage, thermal capacity, earth contacts, and wind velocity as well as temperature, it is unlikely that a simple linear temperature correction will be accurate. It should also be pointed out that heating energy requirements are not strictly a linear function of floor area. In fact, small structures generally use considerably more energy/ft ${ }^{2}$ than large ones. The energy/ft ${ }^{2}$ method makes these small structures seem less effective even though the actual consumption per occupant is lower.

In the proposed NBS low-level measurement, inside temperature, ouside temperature, and auxillary energy input are measured. The performance factors derived are average inside and outside temperacures and normallzed auxlliary energy (Q444). Since load is not considered in the derivation of norwalized energy, it is not possible with this approach to distinguish reductions in heating energy due to solar effects from those due to, for instance, better insulation. In fact, variation in insulation, appliance usage, and heating system efficiencies may be so large that the difference in norwalized energy consumed due to solar effects is completely masked. While this may be useful to those interested in the overall energy impact of passive solar architecture compared to, for instance, the existing housing stock, it does not provide the information desired by many other data users.

In summary, the detalled evaluation rouce demands that accurate measuremenLs be made of heat delivered from the solar and auxiliary systems to the heated space. For the auxiliary system, the heat delivered can be derived from either input energy or auxiliary on-time after a one-time calibration procedure. However, the solar heat delivered w111, in most cases, have to be meas'ured continuously. The instrumentation required to do so is usually extensive and prohibitively expensive. Even when the solar heat delivered can be accurately determined, we still have to face the question of defining the load as the total heat delivered to the space. The "energy saved" factors, based on space heating load ( $Q 415$ and Q416), only allow the building to be compared with itself. Thus, in a direct gain system where space heating load increases with the size of the solar system, the solar energy which displaces 
the load created by the solar system itself is counted as "utilized" solar energy.

The normalized energy for space heating is derived identically for the two levels of measurement. It does not normalize for differences in the following: levels of appliance usage, performance of walls and windows due to solar radiation effects (this will be significant even on east and west exposures), heating systems efficiencies, performance due to thermal capacity, or levels of insulation. Although this index is a useful way of looking at overall thermal performance; it is of very limited use in evaluating solar performance.

\subsection{OTHER PROPOSALS FOR THERMAL PERFORMANCE EVALUATION}

Balcomb et al. [7] of Los Alamos Scientific Laboratory, have proposed therma 1 performance evaluations of passive solar buildings which differ from the NBS proposal, primarily in the definition of "useful" or "utilized" solar energy. In their method, the space heating load is calculated as the product of the building loss coefficient times the degree-hours between the interior temperature of the building and outside air temperature. This bullding loss does not include losses through the solar elements which are part of the envelope. In other words, the load calculation assumes no net heat transfer through the solar elements. Energy saved is then defined as this calculated load minus the actual auxiliary energy required. This procedure has the advantage of requiring continuous measurements only of auxiliary energy. The load calculation method has potential inaccuracies due to heat capacity in the envelope, when there is a slab-on-grade (or similar uninsulated) foundation, due to solar effects on the "non-solar" elements of the building and due to heat gains from lighting and appliances. The exclusion of losses through the solar portions of the envelope is equivalent to comparing the heating energy requirements of the structure in which the solar portion of the envelope has no heat transfer (as if it had a $U$ value of zero).

Andersson and Kammerud [8] have suggested yet another method for determining "energy saved." In this elaborate and detailed procedure, the measured heatIng energy requirements are compared with the calculated heating energy requirements for a "most probable alternative" structure. This is defined as an imaginary building which is identical in a11 respects other than the inclusion of passive solar features. This would be a building of the same general design and insulation level. Rules are given for defining the "most probable alternative" structure.

A storage wall heating solar system would be replaced by a wall of the same construction and percentage of glass as the other walls of the structure. In the case of a sun space, the sun space would be removed. In a direct gain structure south glass is replaced by a wall of the same insulation and percentage of glass as the other walls; however, storage mass in exterior walls 
remains. To determine the heating and cooling loads of a passive solar building, the authors have proposed direct measurement of a "crippled" passive structure. This is the actual passive structure with its passive solar features "crippled" (for example, by covering some glass with insulated shutters). Measurements of heating energy in the "crippled" passfve structure are then compared with the predictions of some building load computer model and the ratio of these numbers will be used to calibrate the model. The model is then used to predict the heating energy requirements of the "most probable alternative." This number minus the actual heating energy required is taken to be the energy saved.

This procedure has the advantage (if occupant behavior is relatively consistent during the crippled and non-crippled phases) that many potential sources of error in comparison unrelated to solar effects are eliminated because the bullding is, for the most part, being compared to itself. Only radiation, auxiliary energy, and inside and outside temperature need to be monftored.

An obvious difficulty with this method is the cost and difficulty of physically crippling any building which is to be evaluated. There could also be problems in deciding which elements should be crippled to accurately represent the "most likely alternative." Another difficulty in this method is its reliance on computer models which are not yet able to adequately deal with the full range of passive solar buildings.

B1iss [9] has proposed determining "energy saved" by comparison with the performance of a structure of the same size, shape, and use which meets HUD MinImum Property Standards, ASHRAE 90-75, or some other current energy conservation standard. The reference structure would have the minimum window area allowable by the codes, distributed equally in all orientations. This method is good for determining the potential savings which can be realized through use of passive solar design over conventional construction practice, but it does not separate the savings attributable to solar energy from those which can be credited to non-solar sources such as insulation, energy-conserving mechanical systems, and different use patterns.

To clarify the nature of the differences in these approaches to performance evaluation and provide a framework for making rational choices among them, the authors of this report have prepared a paper entitled "A Comparison of Performance Factors for Passive Solar Heating." The entire paper is included in Appendix A.

\subsection{WORKING MEETINGS ON LOW-LEVEL MONITORING AND EVALUATION}

A meeting was convened on October 16, 1978 at the Solar Energy Research Institute (SERI) to clarify and discuss the situation regarding performance factors and their associated measurements. All of those attending are par- 
ticipants in government-sponsored research involving the performance evaluation of passive solar bulldings. Those present were:

William Ducas
Douglas Balcomb
Ron Kammerud
Randy Kirk
Greg Gibson
Michael Holtz
Blair Hamilton
Larry Palmiter

\author{
National Bureau of Standards \\ Los Alamos Scientific Laboratory \\ Lawrence Berkeley Laboratory \\ Boeing Aerospace \\ AIA Research Corporation \\ Solar Energy Research Institute \\ National Center for Appropriate \\ Technology \\ National Center for Appropriate \\ Technology
}

Much of the discussion involved a review of the situation and problems outlined in the above sections of this report regarding thermal performance factors. It was agreed that many difficult definitional questions exist, for Instance:

- Under what conditions is a sun space to be counted as part of the heated space?

- Are solar radiation effects on the exterior of the building and east, west, and north glass counted as part of a variable load "seen" by the primary passive solar system?

- Are interior temperature gains above the auxiliary set point counted as "useful" solar energy?

- Should benefits due to the interaction of thermal mass and air temperature be attributed to the passive solar system?

- If the passive system incorporates slab-on-grade or partially underground construction, should all of the energy savings be attributed to the passive solar system?

Many of these questions relate to the definition of the scope of passive solar design, that is, does passive solar design include all "passive effects" (those in which the heat flow is by natural means) or is it restricted to passive solar effects only?

A11 participants agreed the discussion was very helpful in clarifying the problems. The meeting concluded with no resolution of the questions regarding thermal performance factors; however, general agreement was reached on two important observations:

- The process of selecting a small set of performance factors and unfform methods for their evaluation to which all parties might agree is at an 
early stage of its evolution. Consideration of these important questions must be continued, but not rushed.

- Since all of the proposed performance factors depend on the evaluation of certain thermal quantities, it should be possible to obtain agreement on what should be measured, regardless of which methods are used to derive the performance factors. Agreement on general data requirements for varlous uses will allow different data users to develop whatever performance factors they wish until there is commonly accepted resolution of these questions.

Since the primary focus of this project is the specifications of a data acquisition system adequate to determine overall performance of a passive structure, it was suggested that before discussing performance factors, agreement should be reached on the basic varlables to be measured. After some discussion, the following list of primary quantities to be measured was proposed and accepted by all parties:

- Incident radiation in the plane of collection,

- Incident radiation on a horizontal surface,

- Thermal energy from auxillary system to heated space,

- Thermal energy from lights and appliances to heated space,

- Outdoor dry-bulb temperature, and

- Indoor dry-bulb temperature.

Agreement was also reached by the group on a number of other points regarding data requirements for all of the considered users and uses of this proposed low-level data acquisition system:

- A single, hourly value (integral or average) is all that must be acquired for each varlable.

- Summaries of thermal performance data from the most recent one to two days must be avallable on-site. Such summaries should be easily available and understandable (1.e., in engineering units). Preferably, this on-site display should make available both selected thermal performance factors and hourly data for system tuning and analysis.

- Some of the participants felt that they would want hourly data available for off-site analysis elther shortly after it were acquired or at a later time. For this purpose, the hourly data might be saved by some reasonably rellable, accurate, and easily readable method. This effort was not considered worthwhile by all the participants.

- To make comparisons with non-solar buildings, a data-acquisition system should be capable of making the necessary measurements in typical conventional structures. 
- Data acquisition systems should be adaptable to other users when this particular effort ends.

- It is important for many reasons to initiate widespread (100-200 units), low-level monitoring of passive solar buildings as soon as possible. This effort should not be held up by extensive equipment $R \& D$, standardization of thermal performance factors, or detailed development of data analysis programs.

A second brief meeting was held on November 2, 1978 in Washington, D.C. The individuals primarily involved in the discussion included:

Larry Palmiter
Dennis Jones
Elmer Streed
William Ducas
Douglas Balcomb
William Freeborne
Michael Maybaum
Michael Holtz

\author{
National Center for Appropriate \\ Technology \\ National Bureau of Standards \\ National Bureau of Standards \\ National Bureau of Standards \\ Los Alamos Scientific Laboratory \\ Department of Housing and Urban \\ Development \\ Department of Energy \\ Solar Energy Research Institute
}

This meeting included additional discussion of the derivation of various performance factors. Several specific ways of computing solar fraction were presented and analyzed. Again, however, no clear agreement was reached. The authors' appraisal of the situation was that characterization of building thermal performance (the issues were not just solar-related) in terms of a small set of performance factors is still in a formative state. In the transition period a number of factors calculated by different methods may be useful to analysts with various purposes. The present situation creates the necessity for all analysts to use great care in clarifying exactly what algorithms are used in deriving a performance factor. This should perhaps be reinforced with comparative derivations using other methods. 
SER 
SECTION 3.0

DATA REQUIREMENTS

In developing the following specifications the authors have drawn upon the Ideas and suggestions presented in the papers and meetings mentioned previously. The conclusion that data should be acquired and made available for numerous uses and interpretations makes it difficult to arrive at a reasonable 1ist of data requirements. This must be done, at least by examples, to specify a data acquisition system with adequate processing capabilities and to insure that all necessary measured quantities are identified. Accordingly, a proposed list of data requirements is presented and discussed in this section. This should be seen as a typlcal list where various users might replace, delete, or add options, particularly in the list of performance factors. This contains many more factors than would be of interest to most users because it is assumed that the user could select the display and/or recording only of desired factors. For widest usefulness and capability, all data acquisition systems could be capable of processing any of the potentially desired factors upon request.

Most of the data users discussed in the previous section of this report require adequate information for determination of the following:

- Relevant weather conditions at the site during the analysis period;

- Indoor comfort conditions during the period;

- The electrical and/or fossil fuel input energy for auxiliary heating, lighting, and appliances during the period;

- The space heating energy required during the period;

- The space heating provided by the passive solar features during the period; and

- The operating energy required by the passive solar system during the period (if any).

The primary relevant factors of weather can be determined by measurement of outdoor temperatures, solar radiation incident on a horizontal surface, and solar radiation incident on the plane of collection. Although wind will have an effect on heat losses from the building, there is currently no simple method for correlation of heat loss with wind velocity. In most cases, assuming wind effects to be constant should not cause significant error in longterm heat-loss calculations.

Indoor comfort is a function of numerous environmental factors, including drybulb temperature, vapor pressure, radiant temperature, and air movement. For the purpose of preliminary evaluations and equipment specification, dry-bulb temperature will be assumed to be a good index of indoor comfort. 
The energy inputs from electricity and/or fossil fuels can be measured through a combination of one-time and continuous measurements.

The space heating energy required and the passive solar energy input are much more difficult to determine. Once either of these two quantities is determined, however, methods have previously been proposed (see Appendix A) to find the other one. In the additive method (as used, for example, in the NBS proposal for detalled instrumentation), the solar gains (Q4UU) are directlymeasured and added to the auxiliary gains (Q401) to yield the "space heating load" (Q402). In the subtractive method, the solar contribution is determined by subtracting the electric and/or fossil fuel gains from a calculated space heating energy requirement.

Due to both the potential inaccuracies (see Appendix A) of the additive method and excessive cost of direct measurement of solar gains, it is recommended that the subtractive method be employed at this time. Two concepts are involved:

- The reference building loss coefficient: $\mathrm{L}_{\text {ref }}\left(\mathrm{Btu} / \mathrm{hr} \mathrm{r}^{\circ} \mathrm{F}\right)$, and

- The reference temperature: $\mathrm{T}_{\text {ref }}\left({ }^{\circ} \mathrm{F}\right)$.

The reference building loss coefficient ( $\mathrm{L}_{\text {ref }}$ ) is the steady-state heat loss per unit time per unit temperature difference between inside and outside and includes both transmission and infiltration heat losses. A number of possible definitions of $\mathrm{L}_{\text {ref }}$ and the implications of these various definitions are discussed in Appendix $A$. Where movable insulation is used, $L_{\text {ref }}$ may have more than one value and each calculation using $L_{\text {ref }}$ below will have to be made with the corresponding $L_{\text {ref }}$ values for the period within which each value was in effect. Determination of values for $\mathrm{L}_{\text {ref }}$ is discussed in the section on onetime measurement (Section 4.0 of this report).

The reference temperature is defined as the outside temperature at which space heating becomes necessary. As used here, the reference temperature accounts for thermostat set point and heat gain from lights and appliances but does not include solar heat gains. The term "reference temperature" is very similar in definition to the commonly used "balance point temperature," except that balance point temperature normally includes solar heat gains. The reference temperature is defined:

$$
T_{\text {ref }}=T_{\text {set }}-\frac{\dot{\mathrm{Q}}_{\text {app }}}{L_{\text {ref }}}
$$

where

$$
\begin{aligned}
& \mathrm{T}_{\text {ref }}=\text { reference temperature }\left({ }^{\circ} \mathrm{F}\right), \\
& \mathrm{T}_{\text {set }}=\text { thermostat set point }\left({ }^{\circ} \mathrm{F}\right), \\
& \mathrm{L}_{\text {ref }}=\text { loss coefficient }\left(\mathrm{Btu} / \mathrm{hr}{ }^{\circ} \mathrm{F}\right),
\end{aligned}
$$




$$
\begin{aligned}
\dot{Q}_{\text {app }}=\text { rate of heat gain from lights } \\
\text { and appliances during period (Btu/hr). }
\end{aligned}
$$

If there is no net storage of heat, the reference (calculated) space heating requirement of a building (defined here as $Q_{\text {ref }}$ ) over a period of time is given by:

$$
Q_{\text {ref }}=L_{\text {ref }} \int\left(T_{\text {ref }}-T_{0}\right) d \tau
$$

for $\mathrm{T}_{\text {ref }}$ greater than $\mathrm{T}_{0}$.

The space heating energy provided by the passive solar features (defined here as $Q_{\text {so } 1}$ ) can now be defined by subtracting the total heat contribution to the space heating load from the auxiliary heating system (defined here as $Q_{a u x}$ ) from the space heating requirement $\left(Q_{\text {ref }}\right)$ :

$$
Q_{\text {sol }}=Q_{\text {ref }}-Q_{\text {aux }}
$$

Unfortunately, the condition placed on the calculations above, that there be no net heat storage over the measurement period, is not usually the case. The shorter the analysis period, the more massive the structure, and the greater the allowed temperature variation, the larger the resultant error becomes.

An analysis period of a month or more can give fairly satisfactory results even with massive structures. This accuracy can be improved by techniques such as the following:

- Choose an analysis period where the mean daily inside and outside temperatures on the last days are close to those of the first days. This will produce a period in which net storage is closer to zero. The length of the analysis period will become somewhat arbitrary, however, and the data must be scanned to find the matching days.

- Make an empirical correction by estimating the storage effect. The term $Q_{\text {solcor }}$ can be defined as follows and substituted for $Q_{\text {sol }}$ in the calculation of desired performance factors:

$$
Q_{\text {solcor }}=Q_{\text {sol }}+C_{\text {tot }}\left(T_{\text {end }}-T_{\text {begin }}\right)
$$

where

and

$$
\begin{aligned}
& \mathrm{Q}_{\text {solcor }}=\text { corrected solar heat term }(\mathrm{Btu}), \\
& \mathrm{Q}_{\text {sol }}=\text { solar heat term derived as before }(\mathrm{Btu}), \\
& \mathrm{C}_{\text {tot }}=\text { estimated useful heat capactiy of structure }\left(\mathrm{Btu} /{ }^{\circ} \mathrm{F}\right), \\
& \mathrm{T}_{\text {begin }}=\text { mean daily inside temperature on first day }\left({ }^{\circ} \mathrm{F}\right),
\end{aligned}
$$

$$
\mathrm{T}_{\text {end }} \quad=\text { mean daily inside temperature on last day }\left({ }^{\circ} \mathrm{F}\right) \text {. }
$$

- Measure storage temperature(s) directly which will accurately represent the average mass temperature and use this information to choose analysis perlods or correct the calculation. 
$i=$

The recommended base list of data requirements for a low-level acquisition system is presented in Table 3-1. The list contains both direct measurements and factors calculated from site-specific constants and variables. Any of these quantities could be requested for recording and/or on-site summary over a specified period of time. As mentioned earlier, it should be stressed that this base list is not intended to limit the addition of other performance factors, and a data acquisition system should be specified with the capability of providing at least another dozen such factors at some future time.

The defining equations shown in Table 3-1 include a large number of terms which must be determined for each building under evaluation. Definitions of each term and the recommended method for its determination are in the next section of this report. Several assumptions have been made in determining these defining equations. Obviously, this method and these equations apply only to the heating of buildings and do not account for any cooling loads or equipment. Because their inclusion would introduce great difficulties and uncertainties, buildings in which the auxiliary energy source is solid fuel are not dealt with by the recommended methods of this report and are not considered in the formulation of the defining equations of Table 3-1. Similarly, al1 lighting and appliances within the heated space are assumed to contribute all of their input energy to heating of the space with the exception of the water heater (the most significant energy user in most houses). The two most significant appliances which this approach does not deal with are clothes dryers and gas kitchen ranges. Unless these expressions are modified, it is recommended that homes with clothes dryers elther not be evaluated or that the dryers not be used. Similarly, vents to the outdoors from electric kitchen ranges cannot be used and the heat contribution from non-electric kitchen ranges cannot be used and the heat contribution from non-electric ranges must be assumed as a constant $\left(\dot{Q}_{r}\right)$. 
Table 3-1. Data Requirements

\begin{tabular}{|c|c|c|}
\hline DATA REQUIREMENT & $\begin{array}{l}\text { DESIGNATION USED } \\
\text { IN THIS REPORT }\end{array}$ & DEFINING EQUATION \\
\hline Tota1 Horizonta1 Radiation & $I_{h \text { avg }}$ & $\int I_{h} d \tau$ \\
\hline $\begin{array}{l}\text { Total Radiation on Collection } \\
\text { Surface }\end{array}$ & $I_{\text {In avg }}$ & $\int I_{\text {in }} d \tau$ \\
\hline $\begin{array}{l}\text { Average Outdoor Dry-. } \\
\text { Rul, b Temperature }\end{array}$ & $\mathrm{T}_{\mathrm{o}}$ avg & $1 / \tau \int_{\mathrm{T}_{0}}(\tau) \mathrm{d} \tau$ \\
\hline $\begin{array}{l}\text { Average Space Dry- } \\
\text { Bu1b Temperature } \\
\quad \text {. }\end{array}$ & $\mathrm{T}_{1}$ avg & $1 / \tau \int_{T_{i}}(\tau) d \tau$ \\
\hline $\begin{array}{l}\text { Total Heat From Auxiliary } \\
\text { To Space Heating Load }\end{array}$ & $\mathrm{Q}_{\mathrm{aux}}$ & $\begin{array}{c}\eta_{f} 3413 \int E P_{a u x} d \tau \\
+\eta_{f} H V F \int_{f p}+F_{f b} \tau_{f} d \tau\end{array}$ \\
\hline $\begin{array}{l}\text { Total Heat From Lights and } \\
\text { Appliances to Space Heating } \\
\text { Load }\end{array}$ & $\mathrm{Q}_{\mathrm{app}}$ & $\begin{array}{c}E_{e 1 \text { app }}-\int_{E P}\left(1-N_{w}\right) d \tau \\
+H V F \delta N_{w} F_{w} \tau_{w} \cdot d \tau+\dot{Q}_{j} \tau+\dot{Q}_{r} \tau\end{array}$ \\
\hline $\begin{array}{l}\text { Total Reference Space } \\
\text { Heating Load }\end{array}$ & $Q_{\text {ref }}$ & $L_{\text {ref }} \int\left(T_{\text {ref }}-T_{0}\right) d \tau$ \\
\hline $\begin{array}{l}\text { Total Space Heating } \\
\text { Energy Provided by } \\
\text { Passive Solar Features }\end{array}$ & $Q_{\text {sol }}$ & $Q_{\text {ref }}-Q_{\text {aux }}$ \\
\hline $\begin{array}{l}\text { Total Input Electric } \\
\text { Energy For Space } \\
\text { Heating Auxiliary }\end{array}$ & $\mathrm{E}_{\mathrm{aux}}$ & $3413 \int_{\mathrm{EP}}^{\text {a ux }} \mathrm{d \tau}$ \\
\hline $\begin{array}{l}\text { Total Input Fossil } \\
\text { Energy For Space } \\
\text { Heating Auxiliary }\end{array}$ & $E_{\text {aux }}$ & $H V F \int_{f p} \cdot d \tau+H V F \int_{F b}{ }_{f f} d \tau$ \\
\hline $\begin{array}{l}\text { Total Input Electric } \\
\text { Energy to Lights and } \\
\text { Appliances }\end{array}$ & $\mathrm{E}_{\text {e1 app }}$ & $\int_{\text {EP }}$ app ${ }^{\mathrm{d} \tau}$ \\
\hline $\begin{array}{l}\text { Tota } 1 \text { Input Fossil } \\
\text { Energy to Appliances }\end{array}$ & $E_{\text {fos app }}$ & $H V F \int_{F} d \tau+H V F \int_{F} d \tau$ \\
\hline
\end{tabular}




\section{SE尺I*}


SECTION 4.0

MEASURED QUANTITIES

In selecting an approach to instrumentation which will yield the data called for above, a primary criterion is to minimize costs. One method to achieve this is making some measurements on a one-time basis. As the name implies, one-time measurements are performed only once for each structure, and require instrumentation and procedures which are different from those for the continuous monitoring to be done by the data acquisition system. The one-time measurements may vary depending on the details of the building under evaluation. The results of these one-time measurements can then be taken as constants and combined with the continuous measurements of variables made by the data-acquisition system to yield the various selected performance factors. Through the combination of one-time and continuous measurements recommended below, all the variables used in the defining equations of Table 3-1 can be determined.

\subsection{ONE-TIME MEASUREMENTS}

Suggested one-time measurements are given in Table 4-1. They will be discussed in order.

The building heat loss coefficient ( $\mathrm{L}_{\text {ref }}$ ) is the steady-state rate of heat loss per unit temperature difference. This is a critical variable for the evaluation of building thermal performance and determination of "useful" solar energy. As discussed in Appendix $A, L_{\text {ref }}$ can be defined as $L_{\text {tot }}$, $L_{n e t}$, or $\mathrm{L}_{\text {net }}+$ wall . Once a value for $\mathrm{L}_{\text {ref }}=\mathrm{L}_{\text {tot }}$ is determined, the other two can be calculated (all three should be available). Four different options for the estimation of $L_{\text {tot }}$ are suggested. This list of options is not exhaustive and the methods suggested have not been evaluated. While none of these options are without potential problems, the use of such methods appears to be required to keep monitoring costs from rising too high while maintaining reasonable accuracy. The use of any methods such as those listed below will require competent professional judgment in determining applicability to a particular building.

Option 1: If a constant heat source is provided to a non-thermostated building until a quasi-periodic steady-state is reached, the resulting energy consumed per unit time and temperature difference is a good approximation of the building heat loss coefficient. To obtain reasonable accuracy, solar gains must be ellminated by methods such as shading. This is very similar to the calibration procedure proposed by Andersson and Kammerud [10]. 
Table $4-1$. One-Time Measurements

\begin{tabular}{|c|c|c|c|}
\hline MEASURED QUANTITY & DESIGNATION & UNITS & $\begin{array}{l}\text { TARGET } \\
\text { ACCURACY }\end{array}$ \\
\hline $\begin{array}{l}\text { Building Heat Loss } \\
\text { Coefficlent }\end{array}$ & $L_{r e f}$ & $\frac{\mathrm{Btu}}{\mathrm{hr}^{\circ} \mathrm{F}}$ & $\pm 10 \%$ \\
\hline $\begin{array}{l}\text { Overall Furnace } \\
\text { Efficlency }\end{array}$ & $\eta_{f}$ & Dimensionless & $\pm 5 \%$ \\
\hline $\begin{array}{l}\text { Puriate Pllut Puel } \\
\text { Flow Rate (FOR FOSSIL } \\
\text { AUXILIARY) }\end{array}$ & $F_{\mathfrak{f p}}$ & $\frac{g a 1}{l i}$ or $\frac{\mathrm{ft}^{3}}{\mathrm{l}_{11}}$ & $\pm 3 \%$ \\
\hline $\begin{array}{l}\text { Furnace Burner } \overline{F u e} \\
\text { Flow Rate (FOR FOSSIL- } \\
\text { FUEL AUXILIARY) }\end{array}$ & $F_{f b}$ & $\frac{\mathrm{gal}}{\mathrm{hr}}$ or $\frac{\mathrm{ft}^{3}}{\mathrm{hr}}$ & $\pm 3 \%$ \\
\hline $\begin{array}{l}\text { Heating Value of } \\
\text { Fossil Fuel }\end{array}$ & HVP & $\frac{B t u}{g a 1}$ or $\frac{B t u}{f t^{3}}$ & $\pm 2 \%$ \\
\hline $\begin{array}{l}\text { Average Electrical } \\
\text { Voltage to House }\end{array}$ & $v$ & VOLTS & $\pm 2 \%$ \\
\hline $\begin{array}{l}\text { Water Heater Jacket } \\
\text { Losses to ileated } \\
\text { Space }\end{array}$ & $a_{j}$ & $\frac{B t u}{h r}$ & $\pm 10 \%$ \\
\hline $\begin{array}{l}\text { Wacer Heacer Space } \\
\text { Heating Factor }\end{array}$ & $\mathrm{N}_{w}$ & Dimenston less & $\pm 1.0 \%$ \\
\hline $\begin{array}{l}\text { Water Heater Fuel } \\
\text { Flow Rate }\end{array}$ & $F_{\mathrm{H}}$ & $\frac{\mathrm{gal}}{\mathrm{hr}}$ or $\frac{\mathrm{ft}^{3}}{\mathrm{hr}}$ & $\pm 3 \%$ \\
\hline $\begin{array}{l}\text { Kitehcn Range Fuel } \\
\text { Flow Rate (1ong } \\
\text { term average) }\end{array}$ & $F_{r}$ & $\frac{g a l}{h r}$ or $\frac{f t^{3}}{h r}$ & $\pm 3 \%$ \\
\hline $\begin{array}{l}\text { Ritchen Range Heat } \\
\text { Losses to Heated } \\
\text { Space (average) }\end{array}$ & $Q_{5}$ & $\frac{B t u}{h r}$ & $\pm 10 \%$ \\
\hline $\begin{array}{l}\text { Infiltration Loss } \\
\text { Rate (OPTIONAL) }\end{array}$ & $Q_{\text {Inf }}$ & $\frac{\text { BLu }}{h r-{ }^{\circ} F}$ & $\pm 20 \%$ \\
\hline $\begin{array}{l}\text { The rmal Capacity of } \\
\text { Solar Elements } \\
\text { (OPTIONAL) }\end{array}$ & $c_{\text {sol }}$ & $\frac{B t u}{{ }^{\circ} \mathrm{F}}$ & $\pm 10 \%$ \\
\hline $\begin{array}{l}\text { The mal lapacity of } \\
\text { Buflding (OPTIONAL) }\end{array}$ & $c_{b l d g}$ & $\frac{\partial t_{i u}}{{ }^{\circ} \mathrm{F}}$ & $\pm 10 \%$ \\
\hline $\begin{array}{l}\text { Auxillary Set Point } \\
\text { Temperature }\end{array}$ & $\mathrm{T}_{\text {set }}$ & ${ }^{\circ} \mathrm{F}$ & $\pm 0.5^{\circ} \mathrm{F}$ \\
\hline $\begin{array}{l}\text { Area of Solar } \\
\text { Collection }\end{array}$ & $A_{c}$ & $f t^{2}$ & $\pm 1 \%$ \\
\hline
\end{tabular}


Option 2: The total heat input can be measured during periods of cloudy weather. The temperature difference above ambient should be at least $30^{\circ} \mathrm{F}$ to reduce the effects of thermal capacitance and the cloudy period would have to be of some minimum duration (to be determined).

Option 3: The loss coefficient ( $\mathrm{L}_{\text {tot }}$ ) can be determined from the data gathered during the monitoring period by regression analysis. Two forms of regression would be sultable:

1) $Q_{\text {int }} / \Delta T=a+b(I / \Delta T)$

and

2) $Q_{\text {int }}=a+b T_{0}+c I$,

where

$$
\begin{aligned}
Q_{\text {int }}= & \text { total heat released from lights, } \\
& \text { appliances, and auxiliary; } \\
\Delta \mathrm{T} \quad= & \text { the difference between inside and } \\
& \text { outside air temperature; } \\
\mathrm{I} \quad & \text { the total radiation on the collection } \\
& \text { surface; } \\
\mathrm{T}_{0} \quad= & \text { the outside air temperature. }
\end{aligned}
$$

(In determining the loss coefficient; average values over periods of 5 to 10 days should be used.)

Option 4: The loso coefficient cal be calculated using procedures in Chapter 22 of the ASHRAE Handbook (1977-Fundamentals) [11].

Option 1 would be difficult in a bullding already occupled. Option 3 can only be performed in retrospect while option 2 may require a delay after the date of installation. Since this factor is required for the on-site performance summary, only Option 4 might be possible when instrumentation is first installed. Given the potential errors in the Option 4 method, performance factonrs hased on this mcthod would ladve to be taken as tentative estimates. After the period of time necessary to use another method (Options 1-3 or some other), the estimate of the building heat loss coefficient could be improved and the constant used in the on-site summary reset to this new value. Still other methods w11l be required for buildings with significant below-ground losses (such as when the loss through a slab-on-grade 1s greater than $20 \%$ of the total loss). Since this factor is so critical to thermal evaluation, it 
is recommended that many methods be used to determine it until this approach is refined.

In cases where movable insulation is used, the value of $\mathrm{L}_{\text {ref }}$ will vary and will have to be determined for each condition. This may be done either by using one of the above measurement methods more than once or by measuring the area of glazing and thermal resistance of the insulation to make a correction to $\mathrm{L}_{\text {ref }}$ for the intervals when the insulation is in place.

In this effort it is recommended that "overall furnace efficiency" (to be designated as $\eta_{f}$ ) be determined; i.e., the total heat delivered to the heated space divided by the heating value of the fuel consumed per unit time. This is in contrast to conventionally defined furnace efficiencies, which are usinally stcady-ctato, peak valies. Numerous exlsting methods, such as rlut gas analysis, can be used lu wake this measurcment [12]: If the furnare burns fossil fuels and is within the thermal envelope of the building, stack heat losses must be measured. If the furnace is outside the thermal envelope of the building, heat delivered at outlets into the heated space can be measured. This measurement is not easy and requires significant attention if target accuracy is to be achieved.

For fossil fuel furnaces, this efficiency will in most cases vary significantly with the duty cycle of the furnace. To deal with this effect, it may be necessary to measure overall efficiency at several duty cycles (i.e., 10\%, $50 \%$, and $80 \%$ ) and make a different calculation for each hour, based on the cullulative burner on-time.

The volumetric fuel flow rate for gas and ofl to the furnace pilot ( $F_{f p}$ ) can he determined with a line meter (potentially the utilicy meter) whin the main hurner is not on. Similarly, the burner fuel flow rate $\left(F_{f b}\right)$ can be determined by subtracting the pilot flow rate from the overall rate when the burner is on. These volumetric races can subsequently bc converted to energy value. rates by determining the heating value of the fuel (HVF) (for natural gas this varles with source mix and altitude).

Because accurate measurement of both fuel consumption and heating value of the fuel are much more difficult with solid fuels such as coal and wovd, lley are not being considered at this time. While the use of wood as an auxiliary heat sourre appears to be greater in passive solar homes than in other new residential construction, it is felt that eliminating such homes frum present consideration in this program will not be detrimental to the goals of the program. If these measurement obstacles can be overcome, there is no reason that homes with solid-fuel auxillary could not be incorporated into this approach.

Having made the above one-time measurements, integral values of the "auxiliary energy to space heating load" can be derived for oll and gas auxiliary systems by monitoring only the fraction of the time when the furnace burner is on $\left(\tau_{f}\right)$. Similarly, for an electric furnace, only the electric power used $\left(\mathrm{EP}_{\mathrm{aux}}\right)$ need be monitored. The general expression can then be defined: 


$$
Q_{\text {aux }}=\eta_{f} \cdot 3413 \int_{E P} \text { aux } d \tau+\delta \eta_{f}\left(F_{f p}+F_{f p} \cdot \tau_{f}\right) d \tau
$$

From the same measurements, the total input "fossil energy for auxiliary" can be determined

$$
E_{\text {aux }}=H V F \int_{f p} d_{\tau}+\text { HVF } \int_{f b}\left(\tau_{f}\right) d \tau
$$

or alternately; the total input "electric energy for auxiliary"

$$
E_{\text {aux }}=3413 \int \mathrm{EP} \text { aux } \mathrm{d} \tau \text {. }
$$

Average voltage associated with the electrical power supply to a building is listed as a one-time measurement so that it also can be treated as a constant in the calculation of various performance factors. By assuming constant vol.tage and a power factor of one (this should not introduce long-term errors in excess of $\pm 2 \%$ ), only current need be monitored to obtain values for electric power used in heating, lighting, or appliances. An average value (as well as potential variation) could be determined elther from utility company information or direct measurement.

If the variation exceeds $\pm 2 \%$ over the evaluation period of interest, voltage should be considered a variable to be continuously monitored instead of a onetime measurement.

Water heaters can contribute heat to the space heating load through jacket losses and losses from. the heated water used before it leaves the heated space. Jacket losses typically total $14 \%$ of the input energy for an electric water heater [13] and total gains to the space will be typically $30 \%$ of the input energy. If a water heater is not within the building thermal envelope, these losses would be more in the $20 \%$ range. Obviously the amount of hot water usage could affect the heat contribution. Accordingly, it is suggested that a constant value for the water heater jacket losses to the heated space (designated here as $\dot{Q}_{j}$ ) be determined for each building where the water heater is in the heated space. This value will be highly sensitive to the specific installation. The losses from heated water after it leaves the water heater and before it is drained from the heated space will be calculated by the expressions

or

$$
3413 \int_{E P}\left(1-N_{w}\right) d \tau
$$

$$
\operatorname{HVF} \int_{N_{w}} F_{w} \tau_{w} d \tau
$$

depending on whether the water heater is electric, gas, or oil and

where

$$
\mathrm{EP}_{\mathrm{w}}=\text { the measured electric energy input to the water heater, }
$$


HVF = the heating value of the fuel,

$F_{\mathbf{w}}=$ the fuel flow rate,

$\tau_{w}=$ the time that the main burner of the water heater is on,

and

$N_{w}=\begin{aligned} & \text { the fraction of the input energy delivered as heat to the } \\ & \text { space. }\end{aligned}$

The values for $E_{W}$ or $\tau_{w}$ must be continuously monitored. The values for HVF and $F_{w}$ can be determined as one-time measurements using the same method as for furnaces. The value for $\mathrm{N}_{w}$ must be determined either through short-term measurements or standard englneering thermal calculations.

In the case of an electric kitchen range, the heat contribution to the house is included in the measurement of the quantity EP el app . When the range is not electric, however, estimation of the range fuel flow rate ( $F_{r}$ ) and the range heat loss coefficient $\left(\dot{Q}_{r}\right)$ are necessary. While these could be measured continuously they are not significant enough in most cases to merit the cost both of sensing instrumentation and using a separate input channel of the data acquisition system. Accordingly it is recommended that these values be determined by estimating long-term averages and assuming them as constants.

The location of other appliances and lighting should be examined to determine whether their energy use should be treated as a gain to the heated space. As mentioned previously, clothes dryers are not accounted for in this method.

Infiltration and capacitance measurement are not required for calculation of thermal performance factors by the method suggested in this report. Such data would be very useful, however, as a check on the simplifying assumptions which have been made and for analysis which considers infiltration or capacitance effects. Infiltration could be measured by any of a number of state-of-theart methods, including tracer gas decay $[14,15,16]$. Infiltratinn is due to both leakage and induced ventilation, and w111 vary significantly as a function of numerous factors, most critically wind velocity, temperature difference, and whether a vent fan or furnace is on. Thermal capacitance of both the solar (elements exposed to the sun) and non-solar (within the thermal envelope, but not exposed) mass in a building can be either calculated or measured.

The auxiliary set point temperature ( $\mathrm{T}_{\text {set }}$ ) is the indoor space temperature below which the auxiliary heating system comes on. Because calculations are based on the sensed indoor temperature $\left(T_{1}\right)$, it is important that the functioning of the thermostat be consistent with the sensed values of $T_{1}$. It is important in this evaluation method that the $T_{\text {set }}$ used by the occupants be known and remain constant (though at some point calculation adjustments might be made to allow for night set-back of the thermostat). It may be desirable to check the thermostat for variation of the indicated set point from its actual functioning set point. 
The area of solar collection $\left(A_{c}\right)$ is the glazed area through which solar energy is collected (the net area). Because this value is used only for calculating performance factors such as efficiency, it is recommended that only windows specifically defined as "passive solar features" be included.

\subsection{CONTINUOUS MEASUREMENTS}

The following discusses the suggested list of measured quantities which should be monitored continuously as given in Table 4-2.

Incldent solar radiation is not monitored because it is needed for computation of critical performance factors, but rather for purposes of normalization and comparison.

Outdoor dry-bulb temperature is assumed to be uniforin and should be measured at a location which will not be subject to unusual variation due to microclimatic effects. Indoor space dry-bulb temperature must be space averaged. If the building has more than one heating zone, multiple sensors may have to be used. If significant temperature variation exists within a zone, either multiple sensors must be used or a location must be chosen for a single sensor which will yield an average temperature for the space. Averaging of multiple sensors may be accomplished either by using separate input channels to the data logger and averaging in the processing of data or through external hardware summing of the analogue signals; $i . e .$, hooking sensors together in series on a single input channel.

The power to electric heating auxiliary is either the power to an electric furnace or to distributed electric heating elements. The furnace burner operating time is the number of minutes out of an hour that the main burner of a gas or oil furnace is on.

The electric energy to lights and appliances is the total used by all lights and appliances in the heated space including electric water heaters. This will normally be a measurement of all clectric inpul energy in an hour, other than that going to electric space heaters and measured under the EP aux term. As mentioned previously, $100 \%$ of the energy to lights and appliances w1ll be considered as a heat gain to the space in these calculations. Any exceptions to this assumption will require instrumentation or calculation changes.

The electric energy to the water heater or its main burner on-time is measured in the same manner as with a furnace. For an electric water heater, the energy used can be measured by monitoring the water heater circuit. For a gas or oil water heater, the thermostat, fuel flow, and burner temperature go through step changes, any of which could be sensed.

Many passive solar buildings employ movable insulation which will cause a step change in overall heat loss coeffictent of the building. In simple cases, the position of such insulation can easily bc monitored with a switch or relay. 
Table 4-2. Continuous Measurements

\begin{tabular}{|c|c|c|c|c|c|}
\hline CHANNEL & MR:ASUREMENT & DESIGNATION & RANGE & ACCURACY & TYPE OF OUTPUT \\
\hline 1 & $\begin{array}{l}\text { Incident Solar } \\
\text { radiation on } \\
\text { horizontal }\end{array}$ & $I_{h}$ & $\begin{array}{l}0-500 \\
\text { Bty/ } \\
\mathrm{ft}^{2} \mathrm{hr}\end{array}$ & $\begin{array}{l}\text { Within } 3 \% \\
\text { of WMO } \\
\text { Class I } \\
\text { Pyranometer } \\
\text { on daily } \\
\text { total }\end{array}$ & Hourly total \\
\hline 2 & $\begin{array}{l}\text { Incident solar } \\
\text { radiation on } \\
\text { plane on col- } \\
\text { lection }\end{array}$ & $\mathrm{I}_{\text {In }}$ & $\begin{array}{l}0-500 \\
\mathrm{Btu} / \\
\mathrm{ft}^{2} \mathrm{hr}\end{array}$ & $\begin{array}{l}\text { Within } 3 \% \\
\text { of WMO } \\
\text { Clasa I } \\
\text { Pyranometer } \\
\text { on daily } \\
\text { totál }\end{array}$ & Hourly total \\
\hline 3 & $\begin{array}{l}\text { Outdoor dry- } \\
\text { bulb temper- } \\
\text { ature }\end{array}$ & $\mathrm{T}_{0}$ & $\begin{array}{l}-40^{\circ} \text { to } \\
120^{\circ} \mathrm{F}\end{array}$ & $\pm 2^{\circ} \mathrm{F}$ & Hourly average \\
\hline 4 & $\begin{array}{l}\text { Indoor space } \\
\text { dry-bulb } \\
\text { temperature }\end{array}$ & $\mathrm{T}_{1}$ & $\begin{array}{l}40 \text { to } \\
100^{\circ} \mathrm{F}\end{array}$ & $\pm 2^{\circ} \mathrm{F}$ & Hnurly average \\
\hline 5 & $\begin{array}{l}\text { Power to Elec. } \\
\text { heating auxi1- } \\
\text { lary } \mathrm{OR} \\
\text { Furnace burner } \\
\text { operating time }\end{array}$ & $\mathrm{EP}_{\text {aux }}$ & $\begin{array}{l}0 \text { to } \\
20 \mathrm{~kW} \\
0 \mathrm{to} \\
1 \mathrm{hr}\end{array}$ & $\pm 3 \%$ & Fraction of $h r$ \\
\hline 6 & $\begin{array}{l}\text { Electric Power } \\
\text { to lights and } \\
\text { àplianceg }\end{array}$ & $\mathrm{EP}_{\text {el app }}$ & $\begin{array}{l}0 \text { to } \\
20 \mathrm{~kW}\end{array}$ & $\pm 3 \%$ & Hourly total \\
\hline 7 & $\begin{array}{l}\text { Electric puwer } \\
\text { to water heater } \\
\text { OR Water heater } \\
\text { burner oparating } \\
\text { time }\end{array}$ & $\begin{array}{c}E P_{w} \\
\tau_{w}\end{array}$ & $\begin{array}{l}0 \mathrm{to} \\
4 \mathrm{~kW} \\
0 \mathrm{to} \\
1 \mathrm{hr}\end{array}$ & $\pm 3 \%$ & $\begin{array}{l}\text { Hourly total } \\
\text { Fraction of hr }\end{array}$ \\
\hline 8 & $\begin{array}{l}\text { Movabie insul- } \\
\text { ation operating } \\
\text { time }\end{array}$ & $\tau_{\text {ins }}$ & $\begin{array}{ll}0 & \text { to } \\
1 & h r\end{array}$ & $\pm 3 \%$ & Fraction of $\mathrm{hr}$ \\
\hline 9 & Vent operating & $\tau_{v}$ & $\begin{array}{ll}0 & \text { to } \\
1 & \text { hr }\end{array}$ & $\pm 3 \%$ & Fraction of $h r$ \\
\hline 10 & $\begin{array}{l}\text { Solar operating } \\
\text { energy }\end{array}$ & $\mathrm{EP}_{\text {op }}$ & $\begin{array}{ll}0 & \text { to } \\
1 & \mathrm{~kW}\end{array}$ & $\pm 3 \%$ & Hourly total \\
\hline
\end{tabular}

Note: Additional Channels (including 8 and 9 of these features are not in the bullding) would most likely be used for additional temperatures. 
If movable insulation has more than two conditions (open and closed) or if there are several curtains or shutters which do not operate sychronously, additional monitoring channels may be necessary. It might also be possible to combine electronically information on the position of several curtains or shutters into a single signal representative of their combined effect. For the sake of simplicity, it may be desirable to select buildings for evaluation which operate only in two modes.

Most passive buildings also have some provision of venting excess heat. While the methods recommended in this report lose accuracy in considering time intervals where heating loads are not large (the times when venting usually occurs in a well-designed building), some monitoring of heat loss through venting may be desired in certain evaluations. In any such monitoring, the use of a vent will result in an induced infiltration loss which is difficult to measure. A further difficulty is in the measurement itself. If venting is accomplished with a fan, the operating time of the fan can be monitored. If venting is non-mechanical, flow rates will vary widely (this would require that venting be mechanical in monitored buildings). Accordingly, it is recommended that this measurement be considered optional.

In passive or hybrid buildings where mechanical devices such as fans are used as an integral part of the solar features of the building, the electrical in put energy to such devices (EP ${ }_{\text {op }}$ ) must be monitored separately.

In summary, minimal monitoring of most simple passive solar-heated buildings should be possible with about ten continuously measured quantities of four types: solar radiation, temperature, electric power, and status. 


\section{SEㄹ*}


SECTION 5.0

AVAILABLE INSTRUMENTATION

\subsection{AVAILABLE INSTRUMENTATION - SENSORS}

As noted in the previous section of this report, the required sensing instrumentation for low-level data acquisition as proposed in this report is very limited. This is an intentional simplification which should result in both flexibility and economy. While a limited number of buildings may require a more complex approach with different instrumentation, we do not feel that this program need address those requirements. This will limit the applicability of the low-level instrumentation system, but any such buildings of interest might be handled through use of the data acquisition system currently being used in the National Solar Demonstration Program. Accordingly, this discussion is limited to the sensing of temperature, solar radiation, electric power use, and the status of two-mode mechanical elements.

\subsubsection{Temperature Sensors.}

A wide variety of temperature sensors are available that could meet the specifications of this program. Numerous approaches have been taken by the designers of low-cost data acquisition systems to keep within the required accuracy over the specified temperature range at the lowest cost. The cost of any option is not just the sensors themselves, but also any necessary signal conditioning, amplification, linearization, or referencing.

Thermocouples have been the favored temperature-sensing devices in a large number of data acquisition programs on the thermal performance of buildings. The lowest-cost thermocouple wires (such as 24 gauge copper-constantan with PVC insulation for about $\$ .09$ per foot) are commonly used without serious problems. The microvolt-level signal from thermocouples does require amplification, however, before it can be handled by a data acquisition system and this can add to the cost. This low-level signal is also subject to noise problems which sometimes require expensive shielding. Fortunately, such noise should not be a problem in most houses because they do not contain the electrical devices usually responsible for it. The use of a micro-processor in the data acquisition system may facilitate the necessary referencing and linearization of thermocouple inputs.

Resistive temperature-sensing elements can be classifled as either conductors or semiconductors which change their resistance as temperature varies. Of the conductive elements, the most precise and widely used is platinum wire, a1though nickel and several other wires, as well as metal films, could be sufficiently accurate for this application. The most common semiconductor element is the thermistor, although this category also includes germanium crys- 
tals, carbon resistors, silicon crystals, and diodes. All of these devices require an excitation voltage or current. Linearization of the resistance response to temperature must be provided either in the data acquisition system or by use of special linear response probes such as those containing two matched thermistors in the same probe.

The primary problem in the use of thermistors is their potential for long-term drift. With sllicon transistor transducers, such as the Analogue Devices AD590 , the transducer can have a linear response and be sensitive to $0.1^{\circ} \mathrm{F}$ temperature changes, but it will require trimming with two potentiometers on an input board to obtain accuracy better than $\pm 2{ }^{\circ} \mathrm{F}$. This correction can also be done by the software in the data logger. The longer time constant of transducers such as the silicon transistor and diode types could result in excessive error if the data acquisition system does not provide true integration or perform integration through sampling over small enough intervals.

of the six typlcal low-cost data acquisition systems listed in the next section, one uses thermocouples or thermistors, two use thermistors only, one diodes, and two silicon transistors. Any of these could meet the requirement of this program if properly specified and assembled.

Table 5-1 compares the specifications of several typical available sensors for low-cost instrumentation. For all sensors other than the thermocouples, these specifications are taken from the claims of the manufacturers.

\subsubsection{Temperature Sensor Shielding}

Because temperature measurements will be made where radiant heating of the sensing element can be significant, radiation shielding of air temperature sensors w111 be required in most instrumentation of passive solar heated buildings to achieve specified accuracy. Even with the smallest of the potential sensors (an exposed 0.1 in. diameter thermocouple junction) limited tests at the National Center for Appropriate Technology (NCAT) [17] show average readings $16^{\circ} \mathrm{F}$ high for a sensor in direct sunlight and $3^{\circ} \mathrm{F}$ high when shaded compared to a double-shielded sensor. Although meteorological radiation shields are available commercially, they are far too expensive ( $\$ 100$ to $\$ 600$ ) for consideration in this program. Aspiration of such shields is important, but need not necessarily be accomplished with a fan. The simple design tested at NCAT and shown in Fig. 5-1 is probably adequate, though it requires further testing. The vertical mounting of this device when used indoors allows for convective aspiration. It is constructed of two concentric tubes with diameters of 1 1/4in. and 3 in. Satisfactory versions of this device have been produced with less than $\$ 2.00$ material cost and less than an hour fabrication time. 
Table 5-1. Comparison of Typical Available Temperature Sensors for Low-Cost Instrumentation

\begin{tabular}{|c|c|c|c|c|c|c|}
\hline \multirow[b]{2}{*}{. } & \multicolumn{5}{|c|}{ SUPPLIER } & \multirow[b]{2}{*}{ STERFATRONICS } \\
\hline & $\begin{array}{c}\text { NUMEROUS } \\
\text { THERMOCOUPLE } \\
\text { WLRE SUPPLIERS }\end{array}$ & $\begin{array}{l}\text { YEILLOW SPRINGS } \\
\text { INSTRUMENT }\end{array}$ & $\begin{array}{l}\text { YELLOW SPRINGS } \\
\text { INSTRUMENT }\end{array}$ & $\begin{array}{c}\text { ANALOG DEVICES } \\
\text { (AS EROM SOLAR } \\
: \text { DYNAMICS) }\end{array}$ & & \\
\hline DESIGNATTON & $P-2.4-T$ & $44001 \mathrm{~A}$ & 44018 & AD590. ( $K$ Versio & & $\begin{array}{l}\text { Linear } \\
\text { Temperature } \\
\text { Sensors }\end{array}$ \\
\hline TYPE & Thermocouple & $\begin{array}{l}\text { Interchangeable } \\
\text { Thermistor }\end{array}$ & $\begin{array}{l}\text { Interchangeable } \\
\text { Linear Response } \\
\text { The rmi stor }\end{array}$ & $\begin{array}{l}\text { LInear } \\
\text { Sllicon } \\
\text { Transistor } \\
\text { Transducer }\end{array}$ & & $\begin{array}{l}\text { Matched } \\
\text { Dlode } \\
\text { Transducer }\end{array}$ \\
\hline RANGE & $\begin{array}{l}-75^{\circ} \text { to } 200^{\circ} \mathrm{F} \\
\text { (ANSI Standard } \\
\text { C } 96.1 \text { ) }\end{array}$ & $-40^{\circ}$ to $221^{\circ} \mathrm{F}$ & -22 to $221^{\circ} \mathrm{F}$ & $\begin{array}{c}-55 \text { to } 150^{\circ} \mathrm{F} \\
\vdots \\
i\end{array}$ & & -58 to $300^{\circ} \mathrm{F}$ \\
\hline $\begin{array}{l}\text { TYPICAL } \\
\text { ACCURACY }\end{array}$ & $\begin{array}{l} \pm 1.5^{\circ} \mathrm{F} \\
\text { (ANSI standard } \\
\text { C } 96.1 \text { ) }\end{array}$ & $\pm 0.7^{\circ} \mathrm{F}$ & $\pm 0.3^{\circ} \mathrm{F}$ & $\begin{array}{c} \pm 1.8^{\circ} \mathbf{F}^{*} \\
\end{array}$ & 1 & $\pm 1.8^{\circ} \mathrm{F}$ \\
\hline $\begin{array}{l}\text { TIME CONSTANT } \\
\text { IN STILL AIR }\end{array}$ & $5.0 \mathrm{sec}$ & $10.0 \mathrm{sec}$. & $10.0 \mathrm{sec}$ & $35.0 \mathrm{sec}$. & & (unknown) \\
\hline $\begin{array}{l}\text { ES'PIMATED COST } \\
\text { FOR TYPICAL } \\
\text { INSTALLATION } \\
\text { OF THREE SEN- } \\
\text { SOR WITH } 50^{\prime} \text { (FF } \\
\text { WIRE EACH (quan- } \\
\text { tity prices) }\end{array}$ & $\$ 13.50$ & $\begin{array}{l}\$ 16.00 \\
\text { (The rmistors } \\
\$ 4.10 \text { each) }\end{array}$ & $\begin{array}{l}\$ 28.00 \\
\text { (Therm1 stors } \\
\$ 7.80 \text { each) }\end{array}$ & $\begin{array}{l}\$ 32.00 \\
\text { (Transducers } \\
\$ 9.00 \text { each) }\end{array}$ & & $\begin{array}{l}\$ 13.00 \\
\text { (Transducers }\end{array}$ \\
\hline $\begin{array}{l}\text { AUXIL LARY } \\
\text { CIRCUITRY } \\
\text { REQUIRED }\end{array}$ & $\begin{array}{l}\text {-Amplification } \\
\text {-LInearlzation } \\
\text { - Reference } \\
\text { voltage }\end{array}$ & $\begin{array}{l}\text {-Excitation } \\
\text {-Linearization }\end{array}$ & -Excitation & $\begin{array}{l}\text {-Exc1tation } \\
-2 \text { potertio- } \\
\text { meter tritinming } \\
\text { of output }\end{array}$ & & -Excitation \\
\hline
\end{tabular}




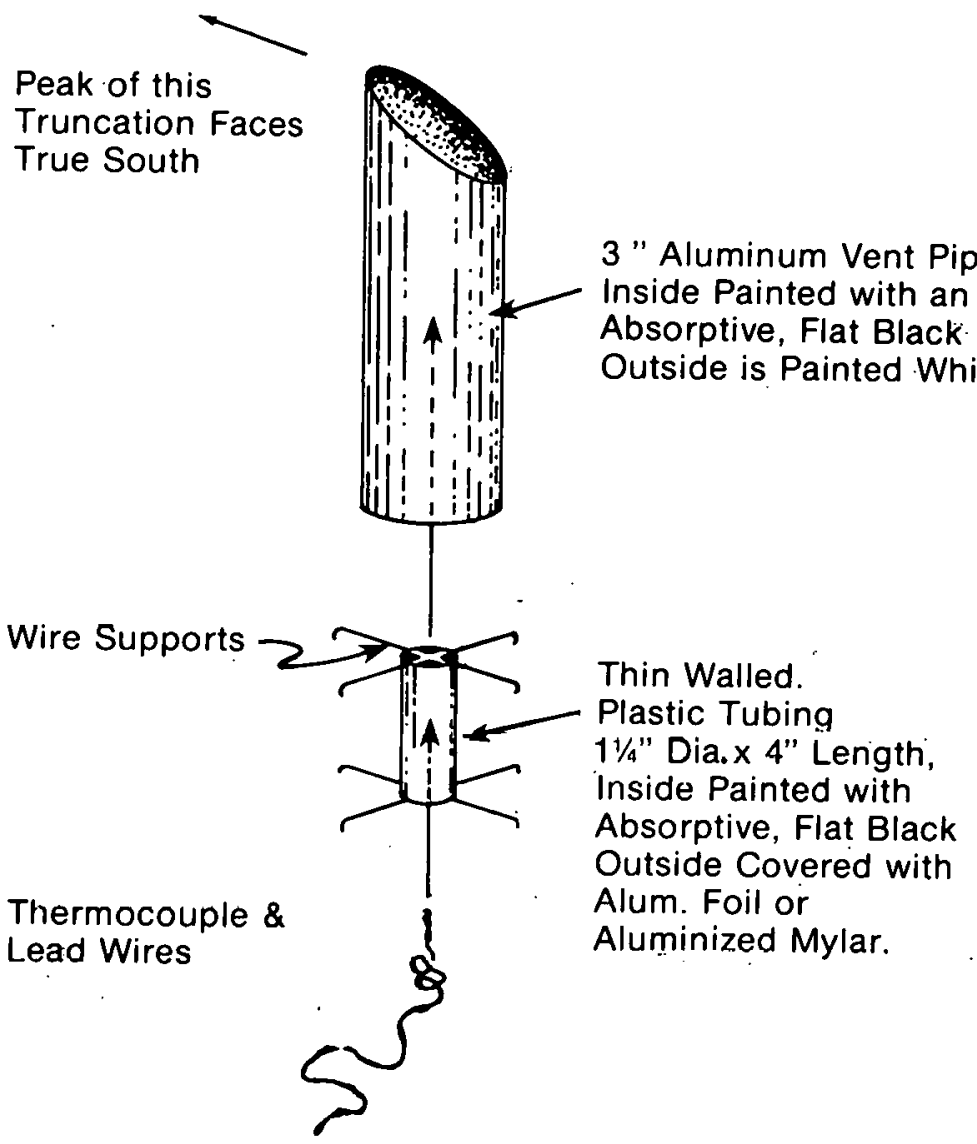

Flgure 5-1. Radiation Shield

\section{b.1.3 Solar Radiation Sensors}

A large number of solar radiation sensors are now avallable at costs varying from less than $\$ 100$ to over $\$ 1000$. The World Meteorological Organization (WMO) has established standards for classification of such instruments and most scientific work in the solar energy field and official, meteorological. stations speclfy WMO Class I instruments for the measurement of total incident solar radiation. Unfortunately, these quality instruments are at the upper end of the cost range and until recently, there has not been adequate comparative information on the lower priced sensors. Preliminary tests made in 1977 comparing most avallable sensors have now been reported by Flowers $[18]$. Table 5-2 lists the sources and approximate cost of the instruments evaluated.

The instruments were evaluated to determine overall error compared to a WMO Class I instrument (an Eppley PSP) as well as the specific errors due to tilt and temperature.

The Eppley PSP, Spectrolab SR-7.5, Lambda, Matrix, and Schenk pyranometers were not significantly affected by tilt, but the others had tilt errors as high as $10 \%$. 
Table 5-2. Solar Radiation Sensors

\begin{tabular}{|c|c|c|}
\hline INSTRUMENT & SOURCE & $\begin{array}{l}\text { APPROXIMATE COST } \\
\text { (1976 DOLLARS) }\end{array}$ \\
\hline Eppley PSP & $\begin{array}{l}\text { Eppley Laboratory, Inc. } \\
12 \text { Sheffield Avenue } \\
\text { Newport, RI } 02340\end{array}$ & 990 \\
\hline Eppley 8-48 & $\begin{array}{l}\text { Eppley Laboratory, Inc. } \\
12 \text { Sheffield Avenue } \\
\text { Newport, RI } 02340\end{array}$ & 590 \\
\hline$P-8405-A-0-1-120$ & $\begin{array}{l}\text { Hy-Cal Englineering } \\
12105 \text { Los Nietos Rd. } \\
\text { Sante Fe Springs, CA } 90670\end{array}$ & 475 \\
\hline 28AM505, Mini & $\begin{array}{l}\text { Kah1 Scientific Instruments } \\
\text { P.0. Box } 1166 \\
\text { E1 Ca jon, CA } 92022\end{array}$ & 555 \\
\hline 28AM100 (Schenk) & $\begin{array}{l}\text { P. Schenk } \\
\text { Gse.m.b.H Wien \& Co., KG } \\
1212 \text { Wien, Austria }\end{array}$ & 560 \\
\hline CM6 mode1 & $\begin{array}{l}\text { Kipp and Zonen } \\
\text { P.0. Box } 507 \\
\text { Delft, Holland }\end{array}$ & 478 \\
\hline LI-200s with $2200 \mathrm{~s}$ & $\begin{array}{l}\text { Lambda Instruments Corp. } \\
4421 \text { Superior Street } \\
\text { P.O. Box } 4425 \\
\text { Lincoln, NE } 68504\end{array}$ & 102 \\
\hline Dome Solarimeter & $\begin{array}{l}\text { Lintronic Limited } \\
54-58 \text { Batholnmew C1n.se } \\
\text { London, EC } 1\end{array}$ & 139 \\
\hline Mk 1-G Sol-A-Meter & $\begin{array}{l}\text { Matrix Inc. } \\
537 \text { South } 31 \text { st St. } \\
\text { Mesa, AZ } 85204\end{array}$ & 195 \\
\hline 4046 mode1 & $\begin{array}{l}\text { Spectran Instruments } \\
\text { P.O. Box } 891 \\
\text { La Habra, CA } 90631\end{array}$ & 890 \\
\hline SR-75 model & $\begin{array}{l}\text { Spectrolab, Inc. } \\
\text { I2500 Gladstone Avenue } \\
\text { Sylmar, CA } 91342\end{array}$ & 1235 \\
\hline 1008 mode 1 & $\begin{array}{l}\text { Rho Sigma, Inc. } \\
11922 \text { Valerio Street } \\
\text { North Hollywood, CA } 91605\end{array}$ & 130 \\
\hline
\end{tabular}


The Eppley and Spectrolab pyranometers have temperature compensation circuits which reduce the temperature response of the instruments to within $\pm 1 \%$ in most cases. The photovoltaic instruments (Lambda, Matrix, and Rho Sigma) were not tested for temperature response, but should be relatively free of temperature error. The other instruments (Lintronic, Kipp, Schenk, Kah1-Mini, Spectran, and $\mathrm{Hy}-\mathrm{Ca}$ ) show errors in excess of $\pm 2 \%$ due to reasonable variation in ambient temperature and would require a correction based on measured temperature in processing their outputs to improve accuracy.

Comparative outdoor tests for various lengths of time showed a11 the pyranometers other than the Lintronic, Kahl-Mini, and Hy-Cal to agree reasonably well with the class I reference instruments. In terms of hourly departure from the reference on a cloudless day, the Lambda, Kipp, and Eppley 8-48 were classlfled is "guod", the Matrix, Schenk, Spcctran, and Rho Sigma as "fair" and the others as "poor".

On the whole, it is interesting that the lowest priced instrument tested compared more favorably with Class I sensors than other. instruments for many times the cost. Although further comparisons and analysis are obviously needed, there are clearly some lower-priced pyranometers on the market which can fulfill the needs of this program within the suggested specifications for accuracy (within $3 \%$ of a Class $I$ pyranometer for daily total radiation in the plane of the collector).

\subsubsection{Electric Power Use Sensors}

The domestic use of electrical power can be measured using any of several commercially available transducers. The best way to do this would be with a transducer which measures both voltage and current. Watt transducers which accomplish this include digital processing, Hall Effect, and thermal types. The Hall Effect transducers are generally the least expensive of these and have an accuracy of $\pm 0.5 \%$ of a reading. The other types w111 not be discussed here due to their higher cost and unnecessarily better accuracy (up to $\pm 0.1 \%)$. Typical costs for Hall Effect transducers are about $\$ 10$ for the $1 \mathrm{~kW}$ size, $\$ 180$ for the $4 \mathrm{~kW}$ size and $\$ 200$ for the $20 \mathrm{~kW}$ size with quantity discounts of as much as $25 \%$. Accordingly, in a typical house with electric heat, the total cost of watt transducers for this low-level monitoring program would be on the order of $\$ 450$ to $\$ 600$.

An alternative method for sensing electrical power use is to monitor the current flow by use of a current transducer or transformer. This approach is based on the assumption that the voltage in most homes is essentially constant and can be determined by one time measurement or information from the utility. It is also assumed that the phase shife of current with respect lu voltage in non-resistive loads will not introduce significant errors. Particularly if all data is to be dealt with in hourly averages, information from several utilities indicates this assumption should not introduce errors in hourly calculations greater than $\pm 2 \%$. If the voltage is to vary signifi- 
cantly it may be desired to monitor voltage independently. Low-cost Ha11 Effect current transducers suitable for measuring up to 200 amps and with $\pm 1 \%$ linearity can be purchased from commercial sources for about $\$ 50$ each, with discounts of up to $30 \%$ for large quantities. This would result in a cost of $\$ 150$ for the typical home monitoring mentioned above.

An even less expensive current sensor is a simple current transformer. Phillips Control of Denver, Colo. fabricates such transformers for use with their domestic "Load Management Controllers". These transformers are constructed of pleces of flat transformer iron with a 5000 turn bobbin and 300 ohm load resistor to give a 0-15 volt output proportional to 0-100 amp current flow. While use of 220 volt, single phase lines requires additional summing circuitry, the transformers alone should cost about $\$ 7.00$ each in quantity. These transformers should not result in current measurements errors of more than $\pm 1 \%$.

\subsubsection{On-Off Sensors}

Several sensors which monitor the condition of an element of the solar or auxiliary system may be required. These may be relays or switches, depending on the particular element. The type selected will vary and need not be precisely specifled other than for durability and reliability.

\subsection{AVAILABLE INSTRUMENTATION - DATA ACQUISITION SYSTEMS}

No low-cost data acquisition system is commerclally available at present which can meet the specified requirements of this program. There are, however, numerous systems which come close to having the required capabilities within the anticipated cost limits. Most of these systems have been research or prototype units, but a few have recently become standard commercial products. A partial survey and description of such systems is presented below.

The common element of all the systems surveyed is their use of a micro-processor. The use of the microprocessors is now becoming almost universal in low-cost data acquisition systems and is the only way to achieve the low-cost, on-site processing specified in this program. Numerous researchers have designed and built micro-processor data acquisition systems in the past several years to monitor the performance of solar heating systems $[19,20,21,22]$. Two approaches have been followed. The first is to start with a microprocessor with limited RAM, ROM, and interfaces, and add peripherals such as keyboards, A/D converters, recorders, printers, and additional memory. This will have a low equipment cost, but must generally be custom designed, may not be very flexible, and may have to be programmed in assembly language. The second approach is to start with a complete low-cost genera1-purpose microcomputer system (such as the many personal computers now being marketed) and add a data 
acquisition front end. This may or may not have a higher initial hardware cost, but offers advantages in easy programmability and flexibility.

Of several systems surveyed, the one which may come the closest to meeting the requirements of this program is that reported by Taylor [23] at Stockton State College in New Jersey. This system was bullt around Motorola M6800 microprocessor and was bullt to monitor the performance of four solar collectors and two heat sturage unlls.

The system uses a CRT terminal, two audio cassette tape recorders, a digital alarm clock/calendar, line printer, and low-cost A/O converter with a 16 channel analogue multiplexer. Reading, conversion to engineering units, recording, and display of data is all accomplished through programming of random access memory (RAM). Two such systems have been built from kito for a total matcrial eost of $\$ 1700$ eacli. As bulli, the syscelns have only $4 \mathrm{~K}$ of RAM and are programmed only to read and record data at set time intervals. The system is designed, however, so that it can perform processing functions between scans if programmed to do so. A similar system could probably meet all the requirements specified in this report with additional memory and programming.

Probably the lowest-cost data acquisition system commercially available today comes from Norman Saunders of Weston, Massachusetts. His 7810 STERATRONICS data loggers have a $\$ 500$ base price and have been used successfully to monitor and evaluate several solar heated bulldings. While this system does not have the capability to perform the on-site processing specified in this project, it does have remarkable capabilities for its price and is a good indicator of what is possible. The standard system has 40 input channels, uses temperature sensors which Saunders sells at 33 for $\$ 100$, and records data on an inexpensive (\$60-\$120) audio cassette tape recorder. At present, data tapes recorded on this system must be sent to Saunders to be read and a printed copy of the data is sent back to the user. He is presently designing a new data logger which will use a microprocessor and which could have all the capabilities required to meet the specifications of this program (additional information can be obtained from Norman Saunders, 15 Ellis Road, Sunshine Circle, Weston, MA 02193).

A second existing commercial source for low-cost data loggers is Solar Dynamics, Ltd. of Austin, Texas. After developing and offering a minfmal system simflar to the STEREATRONICS described above, Solar Dynamics is now offering a microprocessor - controlled data logger (model S923D). The system is built around a National Semiconductor SC/MP 118 bit MNOS microprocessor with a basic $1 \mathrm{k}$ bytes of PROM (additional $2 \mathrm{k}$ or $4 \mathrm{k}$ avallable). RAM is provided in blocks of 256 bytes with 256 in the standard unit. Again, an audio cassette tape recorder is used. Basic cost is $\$ 825$ for a 24-channe1 data logger plus $\$ 139$ to $\$ 199$ for each 8-channel input board. This system could probably meet the requirements specified in this project with only minor modifications such as fewer channels, additional memory and additional programming. (Additional information can be obtained from Solar Dynamics, 3904 Warehouse Row, Suite C, Austin, TX 78704). 
A similar, microprocessor-based system has also been developed by the ECOTOPE Group of Seattle, Washington. After building and using a basic system for monitoring a solar-heated greenhouse [24], they have completed a secondgeneration data acquisition unit which also approaches the requirements of this project. The new system has 15 input channels, flexible sampling rate ( 1 minute increments), channel skip, digital display, internal data buffer, and on-site printer compatability. While they have not sold any units commercially, they project a cost of less than $\$ 1,000$ and are considering the necessary modifications for additional on-site data processing. (Additional information can be obtained from ECOTOPE Group, 2332 East Madison, Seatt1e, WA 98112).

Two other new units are also included in this survey, both of which are now being offered by Campbell Scientific of Logan, Utah. Camphell has manufactured more expensive (but still relatively low-cost) data acquisition systems for a number of years which have been used in many environmental monitoring and solar energy applications. Their two new units are the $C R-21$ and the $C R-7$ (specifications can be obtained from Campbell Scientific, Box 551, Logan, UT 84321). The $C R-21$, as $i t$ is now offered, is a compact, battery-operated "computing data recorder" with 9 input channels. Input data can be integrated or otherwise mathematica1.1.y processed according to factory-programmed routines selected by the user on the keyboard of the logger. Among the processing options which can be selected are averaging, maximum, minimum, standard deviation, conditional sampling, histograms, degree days, and scaling factors where slope and intercept are both user programmable. Cassette tape, telephone telemetry and on-site printer are all offered for data output. Base cost of the $\mathrm{CR}-21$ is $\$ 1,495$. The $\mathrm{CR}^{-7}$ is still under development, but will have most of the capabilities of the CR-21. The primary difference is that the CR-7 will be constructed in modular fashion, allowing for more flexibi11ty, both in inputs and processing. The present specifications on the $C R-7$ indicate that it should be capable of meeting the recommended specifications of this project with only minor modifications and custom programing.

A last example is the approach being used by Fowlkes Engineering (31 Gardner Park Drive, Bozeman, MT) in a program to monitor several solar buildings for the State of Montana. This system uses a Radio Shack hobby computer which is programmable in Level II BASIC. To use the computer as a data logger required the addition of a custom-built front-end for signal conditioning, multiplexing, and $A / D$ conversion of timing and interfacing. The materials cost is approximately $\$ 600$ for the front end with a total systems cost of less than $\$ 2,000$. The great advantage of this approach is that it is easily programmed in BASIC. Programs presently used on this system read the data, calibrate the sensors, convert to engineering units, average over selected time intervals and display on the CRT and/or record on tape. Again, modification of this approach to the requirements specifled in this report appear to be mostly in the addition of memory and new programming. 
The above examples show that the specifications for a data acquisition system recommended in this report are very close to the state of the art. Any of the above manufacturers could probably provide the necessary equipment. It would be difficult, however, to choose one approach or supplier over another without having equipment which actually meets the specifications available for com parative evaluation. This intermediate step will probably be necessary before any system is selected for widespread use. 
The primary intention of this section is to provide a recommended specification for equipment to evaluate the thermal performance of a variety of passive solar bulldings based on the methods and conclusions contained in the preceding sections of this report. This is by no means the only approach which may be successful but is recommended by the authors of this report as the approach which will yleld the most useful and rellable information at the lowest cost.

This specification does not describe the data acquisition system as is customary when such equipment is specified. After much discussion and deliberation, this specification has been limited to a functional description of the requirements for a system. Processing functions are specified in terms of inputs and outputs, but there is no suggestion of exactly how they should be performed. This is recommended because there are a variety of potentially acceptable ways to perform these functions. For example, A to D conversion or integration can be done in hardware or software. Conversion to engineering units could take place at any of several points. User commands and inputs could be made on anything from thumbwheels to a full alphanumeric keyboard. Similarly overall system accuracy is specified instead of accuracy for individual elements of the system. There are a variety of ways to meet such specifications and these choices should be left to the system designer and manufacturer if a minimum-cost system is to be identified.

RECOMMENDED SENSOR SPECIFICATION

\section{Temperature}

Temperature sensors may be of the thermo-electric or the resistive type. They must have a time constant in still air of less than one minute. They must be interchangeable. Precision of temperature difference measurements must be $\pm 0.5^{\circ} \mathrm{F}$ for temperature differences $0-120^{\circ} \mathrm{F}$ under operating conditions of $-40^{\circ} \mathrm{F}$ to $120^{\circ} \mathrm{F}$.

Temperature Sensor Shielding

Temperature sensors must be protected from radiation so that radiative errors do not exceed $\pm 2.0^{\circ} \mathrm{F}$. 


\section{Solar Radiation Sensors}

Solar radiation sensors must have an overall installed accuracy of $\pm 3 \%$ of the value which. would be obtained with a WMO (World Meteorological Organization) Class I pyranometer on any daily total of solar radiation with a mounting anywhere between horizontal and vertical for an ambient temperature range of -20 to $100^{\circ} \mathrm{F}$.

\section{Current Transformers}

Current transformers must have an accuracy of \pm 1.0 amp in measuring purely resistive loads. They must be capable of measuring both 110 and $220 \mathrm{~V}$, single phase circuits carrying $0-20 \mathrm{~kW}$. They should be capable of being easily installed without interrupting existing electric service lines.

\section{On-Off Sensors}

Instrumentation must be provided which will provide a conditional. input to the data acquisition system for various system elements such as:

- furnace main burner on or of $f$,

- movable insulation in place or not, and

- vent open or closed.

This may be accomplished with relays or switches. Devices used must have a minimum time resolution of one minute and be highly reliable and durable. They must minimally be capable of trouble-free, continuous duty (up to 100 condition changes per day) operation for a period of two years.

\section{Data Acquisition System - Inputs Specifications}

- The data acquisition system shall have ten or more input channels.

- Any of the input channels must be capable of recelving input from any of the sensors specified above.

- Inputs must be protected againat damage due to high input vollage.

- There shall be provisions for accommodating input ranges of $10 \mathrm{mV}$ to $10 \mathrm{~V}$ with 3-1/2 digit full-scale resolution for the range being used.

- Input impedence to the system shall be at least $10^{\circ}$ Megohms and have a common mode rejection of $120 \mathrm{~dB}$ at $60 \mathrm{~Hz}$. 


\section{Data Acquisition System - Processing Specifications}

- The user must be able to select the number of channels scanned and instruct the system to skip channels in the scan.

- Linearization, scaling, and other processes for conversion to engineering units of the inputs specified in Table 4-2 must be user-assignable to any input channel.

- Hourly sums or averages (as specifled in Table 4-2) must be avallable for storage or display once an hour. Only these hourly values need be saved after this process is completed. If these values are calculated from scanned Instantaneous values, each input must be scanned at least once every minute of the hour.

- The hourly values for any of the continuously measured quantities for any time interval in the preceding 48 hours must be avallable on-site upon request. These values must be identifled and either displayed or printed in engineering units.

- The hourly values of all selected input channels must be processed for efther magnetic tape recording or telephone telemetry related to offsite processing and data analysis.

- The system must be capable of automatically providing an on-site printed summary of performance at regular intervals of 1-48 hours when the optional printer is attached. This automatic summary mode shall be user-selectable and will contain values for any subset of user-selected performance factors such as those listed in Table 6-1 for the periods between each printout.

- Performance factors including any subset of those 1isted in Table 6-1 shall be computed for any period in the preceding 48 hours upon request and displayed or printed on site. The system sha 11 be capable of computing as many as 30 such performance factors and shall be capable of on-site programming of defining equations for new factors of similar form to those shown in Table 6-1.

- Continuously updated sums or averages of up to 30 user-selected performance factors such as those shown in Table 6-1 must be maintained. The values from these registers shall be displayed or printed upon request or at a pre-set time (and the registers reset to zero if so instructed).

\section{Data Acquisition System - Output Specifications}

- The data acquisition system must have a digital display of at least $31 / 2$ digits.

- The digital display must be capable of displaying the instantaneous sensed values for any input chatuel upon request. 
Table 6-1. On-Site Performance Summary

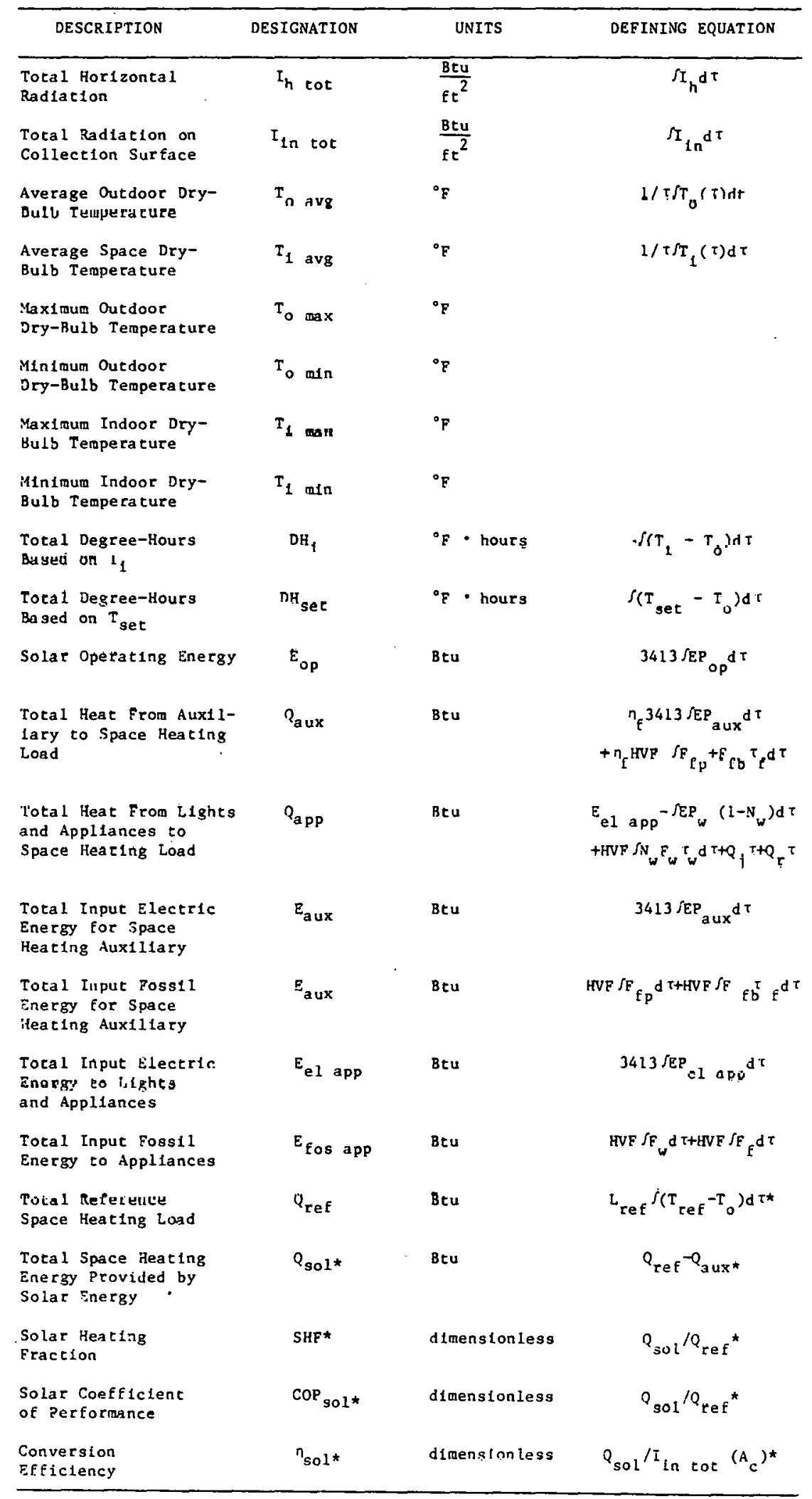

*NOTE: Valucs for $Q_{\text {ref }}, Q_{\text {sol }}, S H F$, GOP sol, and $\eta_{\text {sol }}$ must be selectable for $L_{\text {ref }}=L_{\text {tot }}$, or $L_{\text {ref }}=i_{\text {itet }}$ or $\quad t_{\text {ref }}=\left(i_{n e t}+t_{\text {wa } 11}\right)$ and $T_{\text {ref }}=T_{1}$, or $T_{\text {ref }}=T_{\text {sec }}$ 
- The inclusion of a printer as part of the data acquisition system is optiona1; however, the system must have an RS-232 interface so that a commerclally available printer could be attached to the system if desired for short periods of time. All interfacing required for the attachment of such a printer must be provided as part of the data acquisition system.

- The data acquisition system must output hourly data elther to a recording device or via a modem for telephone telemetry (a system must have one or both). The choice of recording or telemetry will be based on a comparison of total cost and reliability of each approach for a potential system of over 100 installations. Any reading, recelving, and/or processing circuitry and programs necessary for RS-232 input of the recorded or transmitted data to a small, off-site general purpose computer must be provided by the supplier of the data acquisition system as part of the system.

Data Acquisition System - General Specifications

- The system should support an error rate not to exceed 1 reading in 5000 .

- There must be provision to prevent inadvertent modification of programs by those not intending to change programming.

- The overall accuracy of the data acquisition system (from sensors to final output) must not be less than the accuracy specified in Table 4.2 for each hourly value.

- If the system is powered by batteries, they should not require replacement for a period of at least one month. If external (1ine) power is used, back-up power must be provided to operate the system for at least three hours.

- The entire data acquisition system must meet all specifications over an operating range of $50^{\circ} \mathrm{F}$ to $90^{\circ} \mathrm{F}$ and for a period of two years from the date of Installation.

- The system must include a real time clock providing month, day, and hour. The time shall be available upon request as an output associated with any displayed, printed, transmitted, or recorded data.

\section{Off-Site Processing}

The importance of central data processing and analysis is far less under this proposed approach that in most previous performance evaluation programs. A great number of the needs for performance evaluation can be met through onsite processing. Several important functions still remain, however, for offsite processing. 
One critical function which can be performed in off-site processing is improving the calculation of the building loss coefficient ( $\mathrm{L}_{\text {ref }}$ ). Several of the suggested methods for determining this coefficient require the examination of long-term performance data and selecting particular time intervals for evaluation. The longer the period for which data is avallable, the more accurate these methods will be. While such techniques could be performed manually from daily on-site data summarles, central processing will save substantial time and effort.

A second important use of off-site processing is to facilitate producing performance evaluations based on long-term data. Because the hourly data is only stored on-site for 48 hnurs, any analysie which requires hourly data must be done centrally. If a researcher wants to rompute a performancc factor not anticipated prior to data collection, for instance, the original hourly data milght be required.

In addition to calculating performance factors similar to those produced onsite (as in Table 6-1) but with a larger and randomly accessed data base, central processing can also be used for comparative analysis of the data from numerous sites. Validation of thermal models, optimization studies, projections based on normalized climate, and many other research studies could also be carried out in central processing.

Any of several commercially available, small minicomputers would be adequate for this type of off-site processing. The primary considerations in selecting such a system would be compatibility with the data sources, ability to work with a large data base, and availability of suitable statistical analysis sof tware. 
SECTION 7.0

REFERENCES

1. Morse, Frederick H.; Maybaum, Michael W. Commerctal Task Force Reports, Vo1. 4, Direct Applications. 1978 .

2. AIA Research Corporation. Passive Solar Design: A Survey of Monitored Buildings. U.S. Department of Energy, Solar Heating and Cooling Research and Development Branch; Washington D.C.; 1978.

3. Andersson, B.; Kammerud, R. The Determination of Energy Savings for Passlve Solar Bulldings. Lawrence Berkeley Laboratory, Energy and Environment Division, Berkeley, CA: University of California; 1978.

4. Niles, P.; Haggard, K. The Plan to Develop Performance Maps of. Elementary Passive Systems in California. Unpublished Draft. San Luis Obispo, CA: California Polytechnic Institute; 1978.

5. Ducas, W.; Streed, E.; Holten, J.; Angel, W. "Thermal Data Requirements and Performance Evaluation Procedures for Passive Buildings." Passive Solar--State of the Art, Proceedings of the 2nd National Passive Solar Conference. Philadelphia, PA: Mid-Atlantic Solar Energy Association; 1978 .

6. Streed, E.; et al. Therma1 Data Requirements and Performance Evaluation Procedures for the National Solar Heating and Cooling Demonstration Program. Center for Building Technology; Washington, D.C.: National Bureau of Standards; 1976; NBSIR 76-1137.

7. Balcomb, J. D.; McFarland, R. "A Simple Empirical Method for Estimating the Performance of a Passive Solar Heated Bullding of the Thermal Storage Wall Type." Passive Solar--State of the Art, Proceedings of the 2nd National Passive Solar Conference. Philade1phia, PA: Mid-Atlantic Solar Energy Association; 1978.

8. Andersson, B. and Kammerud, R. 1978. op cit.

9. Bliss, R. "Direct Solar Heating -- Why Not Just Let the Winter Sun In the Windows?" Proceedings of Consumer Conference on Solar Energy Deve1opment. Albuquerque, NM: October 1976 .

10. Andersson, B. and Kammerud, R. 1978. op cit.

11. American Society of Heating, Refrigeration and Atr Conditioning Engineers. Handbook of Fundamenta1s. New York, NY: (ASHRAE); 1977. 
12. Socolow, R. (Ed.). Saving Energy in the Home - Princeton's Experiments at Twin Rivers. Cambridge, MA: Ballinger; 1978 .

13. Hoskins, R. and Hirst, E. Energy and Cost Analysis of Residential Water Heaters. Report ORNL/CON-10, Oak Ridge, TN: Oak Ridge National Laboratory; 1977.

14. Burch, D.; Hunt, C. Retrofitting an Existing Wood-Frame Residence for Energy Conservation. Center for Building Technology; Washington D.C.: National Bureau of Standards; 1978.

15. Socolow, R., Ed. 1978. op c1 2 .

16. Robinson, D. "A Soląr Assisted Super-Tnşlatod Houdo." Proceedings of 3rd National Passive Solar Conference. San Jose, CA; January 1979.

17. Wadsworth, B. Thermocouple Radiation Shielding. Technical Report. National Center for Appropriate Technology; Butte, MT; to be published in February 1979.

18. Flowers, E. Comparison of Solar Radiation Sensors from Various Manufacturers. Unpublished Paper. National Oceanographic and Atmospheric Administration; Environmental Research Laboratory; Boulder, Co: Solar Radiation Facility; 1978.

19. Forseth, K.; Thomae, I.; Converse, A. "Microcomputer Processor for Monitoring of Solar Heated Bulldings." Proceedings of the Joint Conference of the American Section of the International Solar Energy Soctety and the Solar Energy Society of Canada. Winnipeg, Manitoba, Canada; August 1976.

20. Moran, W.; Kouba, G. "A Microprocessor Based Solar Monitoring System." Proceedings of Conference on Performance Monitoring Techniques for. Evaluation of Solar Heating and Cooling Systems. Washington D.C.; April 1978.

21. Miche1s, T. "A Low Cost Data Acquisition and Processing System." Passive Solar -- State of the Art, Proceedings of the 2nd National Passive Solar Conference. Mid-Atlantic Solar Fnergy Assoclation; Philadelphia, PA; 1978 .

22. Schlag, J. G.; Sheppard, A. P.; Wood, J. M. "Low Cost Microprocessor Based Data Acquisition System." Proceedings of Conference on Performance Monitoring Techniques for Evaluation of Solar Heating and Cooling Systems. Washington, D.C.; April 1978. 
23. Taylor, H. "A Microprocessor Monitoring System for a Solar Energy Installation." Proceedings of Conference on Performance Monitoring Techniques for Evaluation of Solar Heating and Cooling Systems. Washington, D.C.; Apri1 1978.

24. Brown, E. "A Custom-Built Temperature and Solar Data Collection and Transmission System Based on the Motorola MC6800 Evaluation Kit II." Proceedings of the 1978 Annual Meeting of the American Section of the International Solar Energy Soclety, Inc. Denver, Co; August 1978 . 


\author{
APPENDIX A \\ A COMPARISON OF PERFORMANCE \\ FACTORS FOR PASSIVE SOLAR HEATING
}

A paper presented to the

3rd National Passive Solar Conference, January 1979,

San Jose, California 


\title{
A COMPARISON OF PERFORHAIICE FACTORS
}

FOR PASSIVE SOLAR REATING

\author{
Larry Palmiter and Blair Hamilton \\ Technical Rescarch Staff \\ The National Center for Appropriate Technology \\ P.0. Box 3838 Butte, llontana 59701
}

\section{ABSTRACT}

Interest in passive solar heating is growing rapidly. Owners, builders; architects, engineers, and government officials wish to compare the performance of a particular passive solar heating system with any other passive system, with an active systen, or a conventional structure. The ability to make a fair and accurate comparison is critical in the development of government incentive prograns in solar heating.

A survey of the recent solar literature revr:ils a diversity of suggested performance factors. In additicn; common terms such as "solar fraction: are calculated differently by almost every author. Different definitions applied to the same building can result in a $200 \%$ difference in solar fraction.

The purpose of this paper is to provide some background and perspective on the calculation of performance factors for buildings with passive solar space heating. A side-by-side comparison of perfomance factors calculated by different methods illustrates the importance of this problem. A detailed discussion of the causes of these differences is presented. The choice of methods is related to the needs of various users and recommendations are made which riay alleviate some of the current confusion regarding passive solar performance factorg.

\section{AI: EXAPALE}

The results of using several different methods of calculating performance factors. are shown in Table 1. The heat flows given are based on a detailed hourly computer simulation inodel. The month of November was chosen as representative of the magnitude of the discrepancies between the various livethads. Fonths with milder weather will tend to show larger deviations. Since the econonic eifectiveness of a passive solar design is derived from the heat saved factor, the five-tocne ratio between the highest and lowest values is reflected in a five-to-one variation in the cost effectiveness.

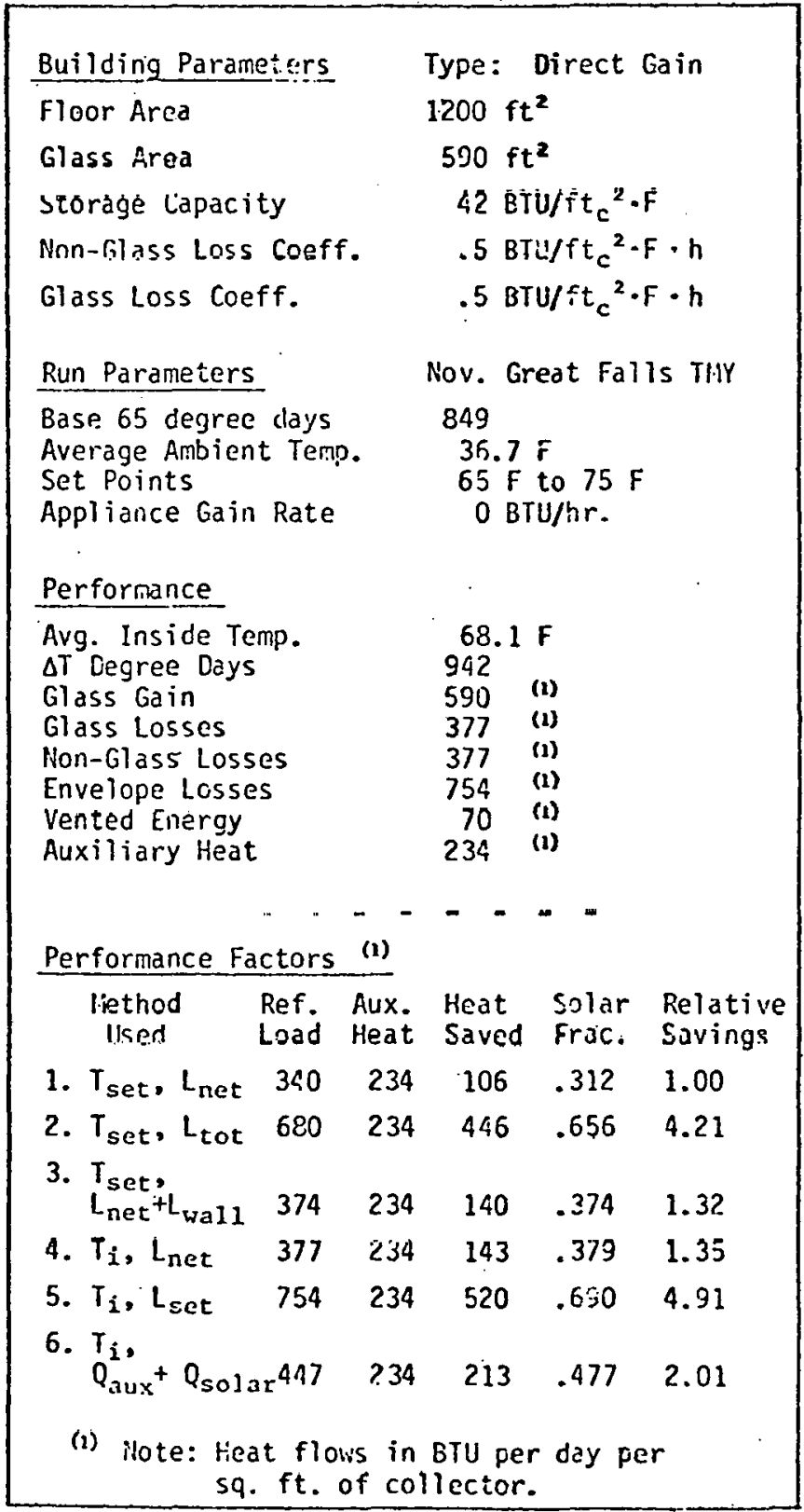

Table 1. Perfornance Factor Comparison 
The designations in the method used column have the following meanings: $T_{i}$ refers to loads based on actual inside temperature, while $T_{\text {set }}$ refers to those based on the heating set point; $L_{\text {tot }}$ refers to loads based on the total loss coefficient of the whole building, while $L_{\text {net }}$ refers to those based on the loss coefficient of the non-solar portions of the envelope only; $L_{\text {wall }}$ is the loss coefficient for a wall which replaces the solar portion of the envelope; and $Q_{a u x}+Q_{\text {solar }}$ refers to a load based on adding the heat delivered by solar systein and heat delivered by the auxiliary system. These terms and methods are now discussed in detail.

\section{ADDITIVE HETHOD}

Let us examine Method 6 first. This method is an extension of the procedures used for the evaluation of active solar systems. A schematic is shown in Figure 1. The critical assumption here is that the heat from the solar system is delivered only on demand from the themostat. Thus, all solar heat delivered is useful and the space heating load can be determined from the addition of the solar and auxiliary contributions (Ref. 1). In this example, Qsolar is the total gain through the glass minus the total loss through the glass (i.e. the net gain through the glass). The heat saved is simply Qsolar, while the solar fraction is defined as $Q_{\text {solar }} /\left(Q_{\text {solar }}+Q_{\text {aux }}\right)$. This is the classic definition of solar fraction. This method has the advantage of being based on the actual space heating load (including the effects of appliance gains and incidental solar gains through winjows) at the actual set point teriperature.

In most actual active solar installations, however, the storage is located in the heated space, thus allowing for uncontrolled heat transfer rrom the storage to the space. At a recent conference, a. number of papers reported uncontrolled delivery to be as much as $40 \%$ of the total solar delivered (Ref. 2). The question then arises as to how much of the heat delivered is "useful," strice il is not delivered on demand from the thermostat. In mild weather it may even become a disbenefit by contributing to overheating of the space.

In systems where the heat delivery is not thermostatically controlled (miost passive systems), the use of the additive method of derivil:g the space heating load may lead to large errors, since the sum of auxiliary and solar heat delivered may far exceed a realistic space heating load.

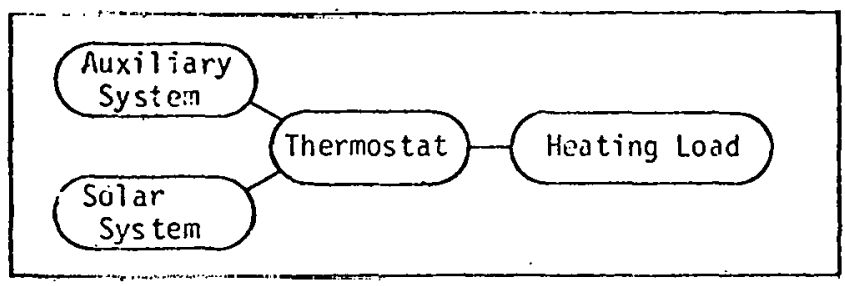

Figure 1. Schematic for active system.

\section{SUBTRACTIVE. METHOOS}

In the subtractive methods, the "useful" solar heat delivered is determined by subtraction of the auxiliary heat delivered from some reference space heating load. It is given by

$$
Q_{\text {saved }}=Q_{\text {ref }}-Q_{\text {aux }}
$$

The solar fraction is given by

$$
F=1-\left(Q_{\text {aux }} / Q_{\text {ref }}\right)
$$

This is the technique most used for the evaluation of passive systems. However, a number of choices enter into the determination of the reference load. As each author has made somewhat different choices, a bewildering variety of methods for deriving perforriance factors are in use.

The choices involved are now discussed in detail. The reference space heating load may be calculated by the following formula:

$$
Q_{\text {ref }}=L_{\text {ref }} \cdot \Sigma\left(T_{\text {ref }}-T_{\text {amb }}\right)_{i}
$$

With the condition

$$
\left(T_{\text {ref }}-T_{\text {amb }}\right)_{i}=0 \text { if } T_{\text {ref }} \leq T_{\text {amb }}
$$

where

$$
\begin{aligned}
& T_{\text {ref }}= \text { reference temperature } \\
& T_{\text {amb }}= \text { ambient temperature }(F) \\
& L_{\text {ref }}= \text { reference loss coefficient } \\
& \text { (BTU/F } \cdot h \text { ) }
\end{aligned}
$$

The sum is taken over hourly positive values. The reference load thus has two components, a loss coefficient and a temperature coefficient. These are discussed in order.

\section{REFERENCE LOSS COEFFICIENT}

A major factor in deriving the reference loss coefficient is the choice of load system boundaries. Figure 2 is a conceptual illustration of the three options discussed in this paper. In the first option the reference loss coefficient is taken to be the steady-state conductance of the whole building, including losses through the solar portion of the envelope. We have

$$
L_{\text {ref }}=L_{\text {tot }}
$$

where

$$
\begin{aligned}
L_{\text {ref }}= & \text { reference loss coefficient } \\
L_{\text {tut }}= & \text { steady-state } \\
& \text { conductance of } \\
& \text { the whole building }
\end{aligned}
$$




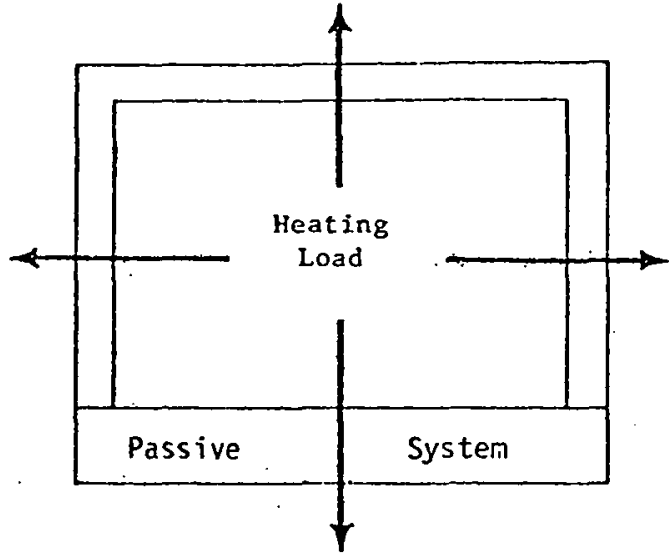

Use of total luss coefficient for load Eq. (4)

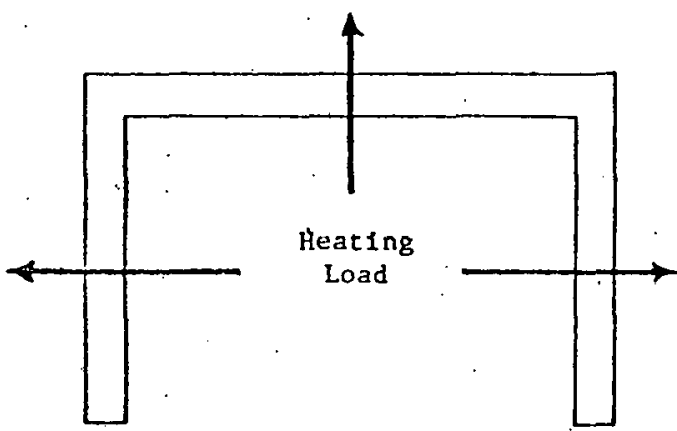

Passive System

Use of net loss coefficient for load Eq. (5)

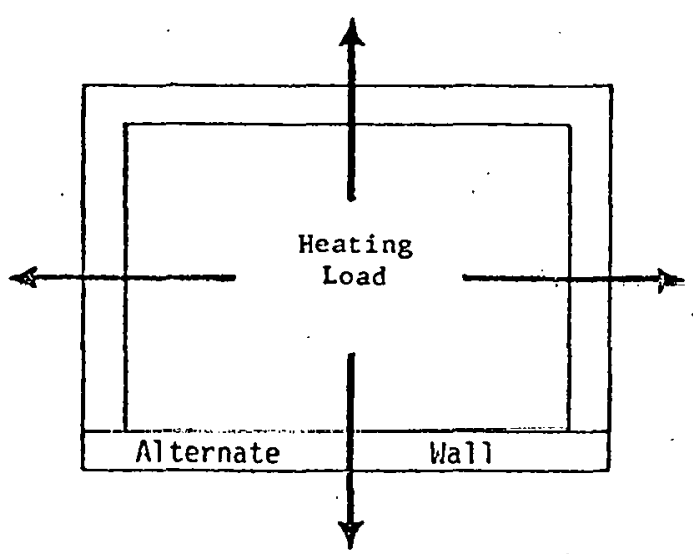

Use of net + wall loss coeffirients for load Eq (6)

Figure 2. Options for choosing reference loss coefficient.
In effect, the auxiliary actually used is compared with that which would be required if there were no solar gains.

Although frequently used, this is not a good measure of the performance of the structure. Consider a direct ga in building in which (heat flows are in BTU per square foot of collector per day)

$\begin{array}{lr}\text { Glass Losses } & =500 \\ \text { Non-Glass Losses } & 500 \\ \text { Total Losses } & =1000 \\ \text { Auxiliary. } & =250 \\ \text { Heat Saved } & =750\end{array}$

For simplicity, assume there is no overheating. Now suppose another glazing system had been used which had the same transmittance for solar radiation and a U-value twice as large. The glass losses are doubled. We now have

$\begin{array}{lr}\text { Glass Losscs } & =1000 \\ \text { llon-Glass Losses } & 500 \\ \text { Total Losses } & =1500 \\ \text { Auxiliary } & =750 \\ \text { Heat saved } & =750\end{array}$

The heat saved is the same in both bases, even though the amount of auxiliary required has tripled! Thus, the calculated savings are independent of the $U$-value of the glazing system and the amount of axiliary required. This choice of reference load nicasures only solar gains. It does not properly account for losses through the solar portion of the envelope.

In the second option the solar portions of the envelope are conceptually isolated from the rest of the building (Ref. 3). The reference loss coefficjent is taken to he the steady-stato conductance of the non-solar portion of the building only. We have

$$
L_{\text {ref }}=L_{\text {net }}
$$

whère

$$
\begin{aligned}
L_{\text {net }}= & \text { steady-state conductance } \\
& \text { of non-solar portion of } \\
& \text { the building }
\end{aligned}
$$

All heat lost through the solar portion is thus counted as a disbenefit. In effect, the solar wall is compared with an adiabatic wall, that is, a vall which allows no heat transfer. The "useful" heat is the reduction in auxiliary required to mect the non-solar purtion of the load. Since each solar system is essentially compared with an absolute standard, an adiabatic wall, this option allows for a fair comparison of different systems. However, from a whole building vievpoint, it does not provide a complete measure of $s$ evings, because all losses through the solai purlion are taken as disbenefits although any real wall which the solar system replaces would also have losses.

In the third option the reference loss coefficient is taken as the steady-state conductance of the 
building with the solar portion replaced by an alternative wall without solar effects (Ref. 4,5 ). We have

$$
L_{\text {ref }}=L_{\text {net }}+L_{\text {wall }}
$$

visere

$$
\begin{aligned}
L_{\text {wall }}= & \text { steady-state conductance } \\
& \text { of alternative wall }
\end{aligned}
$$

The choice of an alternative wall is somewhat arbitrary. If performance factors based on this option are used, some effort would have to be made to standardize the choice of an alternative wall. One reasonable procedure would be to choose a wall with the same $U$-value as the average of the other walls (including windows). This gives

$$
L_{\text {wa11 }}=A_{\text {wa11 }} \cdot U_{\text {avg }}
$$

where

$$
\begin{aligned}
& A_{\text {wall }}=\text { area of alternative wall } \\
& U_{\text {avg }}=\begin{array}{l}
\text { average } U \text {-value of } \\
\text { non-solar walls }
\end{array}
\end{aligned}
$$

It should be noted that since the options for the reference loss coefficient are based on steadystat.e conductance, the effects of thermal capacitance, solar radiation, and earth contact on the non-solar portions of the building load are not made explicit. Any reduction of space heating load due to these effects will, in the procedure outlined here, be attributed to the passive solar system. In many cases this is acceptable, since slab-on-grade flooring or massive exterior walls fur a direct gain structure may be considered as integral features of the passive solar design. The gains from extensive east or vest glazing should be accounted for explicitly. This can be done at the hand calculation level by adding the monthly average rate of gain from east and west glazing to the appliance gain rate in the derivation of a monthly reference temperature. Proper accounting for these effects will require hourly measurement and simulation studies.

\section{REFERENCE TEMPERATURE}

The temperature component of Eq. (3) is given as

$$
\Sigma\left(T_{\text {ref }}-T_{\text {amb }}\right)_{i}(F \cdot h)
$$

It has been shown that the choice of $T_{\text {ref }}$ can make differences of as much as $40 \%$ in the calculation of annual solar fraction (Ref. 6,7 ). Figure 3 illustrates the relationship of ambient, inside, and set point temperatures to the temperature integrals used in calculating the load. If we let

$$
T_{\text {ref }}=T_{i}
$$

we are comparing the auxiliary used by the passive building with the auxiliary that would be required by a non-solar building of the same load coefficient operated so as to match the temperatures actually attained in the passive structure. Thus, any temperature gains above the set point are counted as "useful" solar heat. If the structure were allowed to overheat, the energy which produced the overheating would also be taken as "useful." This does not seem desirable.

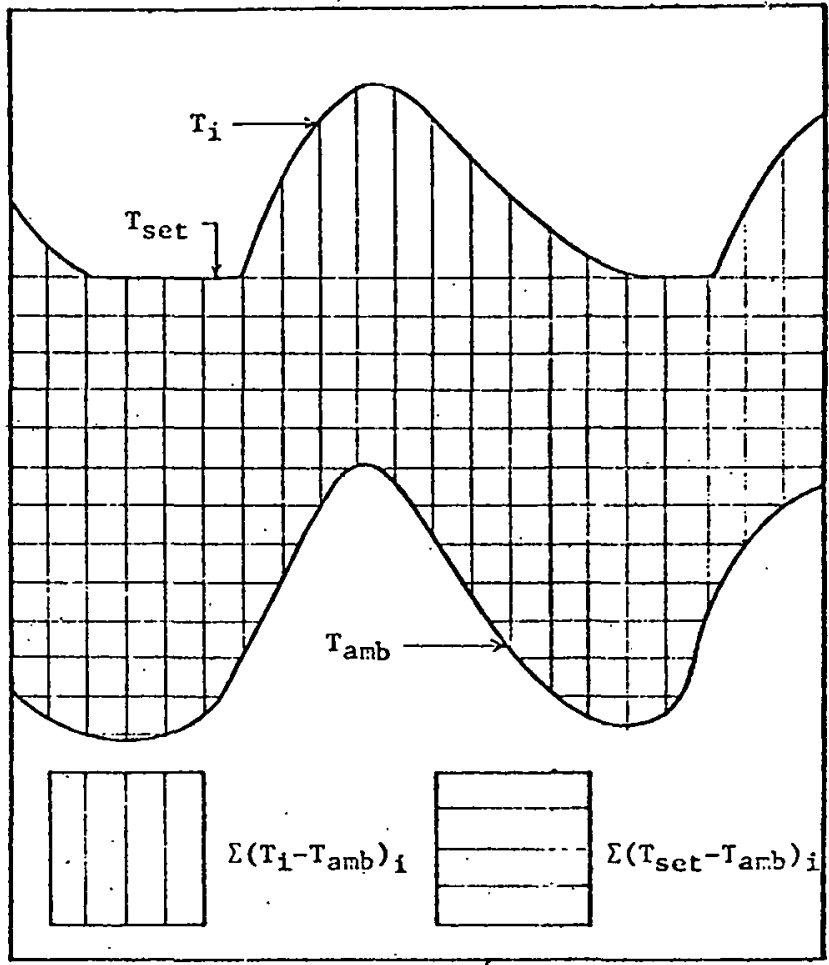

Figure 3. Relationships of inside, ambient, and set point temperatures to temerature integrals used in load calculation.

A second option is to let

$$
T_{\text {ref }}=T_{\text {set }}
$$

This corresponds to the conventional calculation for space heating load. It counts as "usefuT" only that energy which is required to raintain the structure at sone minimum al lowable inside temperature. For this reason it provides the most consistent comparison with the performance of a conventional structure.

Another important influence on the thermal performance of a building is the internal heat generated by the use of lights and appliances. In a very. well-insulated structure these gains may supply $30 \%$ to $50 \%$ of the space heating load. Therefore, it is very deceptive to use performance factors which do not explicitly account for appliance gains. For a hand calculation it is adequate to assume the appliance gains occur at a constant rate, while in more detailed computer analysis use is made of an operating schedule. In either case, the effect of appliance gains on space heating load can be included in the reference. 
tenperature. We have

$$
T_{\text {ref }}=T-Q_{\text {app }} / L_{\text {ref }}
$$

where

$$
\begin{aligned}
& T=T_{\mathbf{i}} \text { or } T_{\text {set }} \\
& Q_{\text {app }}=\text { rate of appliance gain (BTU/hr) } \\
& L_{\text {ref }}=\text { reference loss coefficient }
\end{aligned}
$$

The inclusion of appliance gains in the temperature integral is more realistic than simply subtracting them from the space heating load, as is often done, since the latter method counts all appliance energy as a reduction in load, regardless of interior tenperatures.

\section{OTHER CONSI DERATIONS}

The analys is given here assumes that no energy is required to operate the passive solar system. The performance factors are based on displacement of space heating load and do not account for any additional energy whichmay be required to attain this displacement. Any analys is of overall energy or cost savings due to the presence of a solar system must, of course, take operating energy into account (Ref. 8).

Th is paper considers passive systems only in the context of space heating. The presence of the passive system will, in general, also effect cooling loads. An analysis similar to the one given here can also be developed for the cooling case. The two cases should then be combined to produce an annual performance factor which accounts for both heating and cooling. loads.

\section{SUP:H.ARY}

The derivation of performance factors such as solar fraction and energy saved for passive solar systems is more complex than appears at first sight. The amount of auxiliary actually used is compared with a reference space heating load. Options for computing the reference space heating load are anaijzed as combinations of a choice of reference loss coefficient and a choice of reference temperature. The resulting differences in the calculated performance factors are illustrated with a specific example. Considering the present diversity of calculation procedures, it is suggested that performance factors always be presented with an explanation of the method used to derive then. Without this additional information, the performance factors are almost meaningless.

\section{ACKNOMLEGERENTS}

The authors wish to thank the following persons for their participation in many helpful discussions on this subject.
D. Balcolmb, LASL
H. Ducas, NBS
R. Kammerud, LBL
S. Noll, LASL

T. Wheeling, NCAT

Appreciation is also due S. Eisenbart of the NCAT staff for preparation of the final copy.

\section{REFERENCES}

1. Ducas, H., et al, "Thermal Data Re - irements and Performance Evaluation Proceduris for Passive Buildings". Proceedings, 2nd National Passive Solar Conference, Philadelphia, PA, March 16-18, 1978.

2. Preconference Proceedings, Solar Heating and Cooling Systems Operational Results Conference, Colorado Springs, C0, Nov. 28 - Dec. 1, 1978.

3. Ba?comb, J.D., and R.D. McFarland, "A Simple Empirical Hethod for Estimating the Performance of a Passive Solar Heated Building of the Thermal Storage lall Typen. Proceedings, 2nd National Passive Solar Conference, Philadelphia, PA, March 16-18, 1978.

4. Bl iss, R., "Direct Solar Heating". Proceedings, Consumer Conference on Solar Energy Developmenț. Albuquerque, NH, nct. 2-5, 1976.

5. Anderson, B., and R. Kammerud, "The Determination of Energy Savings for Passive Solar Buildings". LBL-7886́, UC-95d, LBL, Sept. 1978.

6. Noll, S., "A Note on Alternative Definitions of Sülai Fraclion." Uirpublished mânuscript, 1978.

7. Palmiter, L., ct al, "Pcasured and Hodeled Passive Perfornance in Montana". Proceedings, ISES American Section Conference, Denver, CO, Aug. 23-31, 1978.

8. Palluiler, L., "Notes on Extending the Concept of Solar Fraction". Unpublished manuscript, Nov. 1978. 


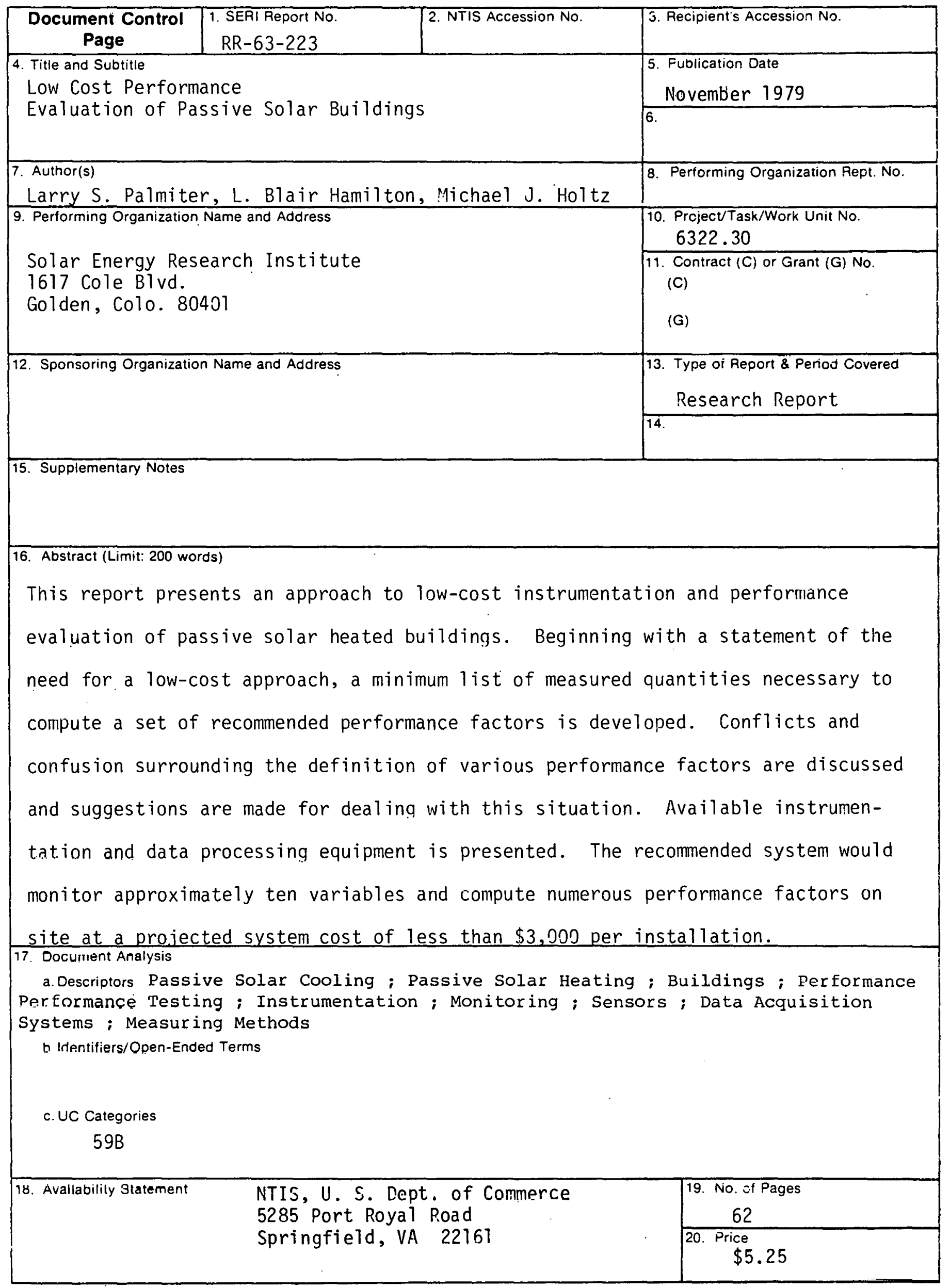

